\title{
Early Cenozoic Eurekan strain partitioning and decoupling in central Spitsbergen, Svalbard
}

\author{
Jean-Baptiste P. Koehl ${ }^{1,2,3,4}$ \\ ${ }^{1}$ Centre for Earth Evolution and Dynamics (CEED), University of Oslo, P.O. Box 1028 Blindern, 0315 Oslo, Norway \\ ${ }^{2}$ Department of Geosciences, UiT The Arctic University of Norway in Troms $\varnothing, 9037$ Troms $\varnothing$, Norway \\ ${ }^{3}$ Research Centre for Arctic Petroleum Exploration (ARCEx), University of Troms $\varnothing, 9037$ Troms $\emptyset$, Norway \\ ${ }^{4} \mathrm{CAGE}$ - Centre for Arctic Gas Hydrate, Environment and Climate, 9037 Troms $\varnothing$, Norway
}

Correspondence: Jean-Baptiste P. Koehl (jean-baptiste.koehl@uit.no)

Received: 30 September 2020 - Discussion started: 19 October 2020

Revised: 22 March 2021 - Accepted: 6 April 2021 - Published: 10 May 2021

\begin{abstract}
The present study of field, petrological, exploration well, and seismic data describes backward-dipping duplexes comprised of phyllitic coal and bedding-parallel décollements and thrusts localized along lithological transitions in tectonically thickened Lower Devonian to lowermost Upper Devonian; uppermost Devonian-Mississippian; and uppermost Pennsylvanian-lowermost Permian sedimentary strata of the Wood Bay and/or Wijde Bay and/or Grey Hoek formations; of the Billefjorden Group; and of the Wordiekammen Formation, respectively. The study shows that these structures partially decoupled uppermost Devonian-Permian sedimentary rocks of the Billefjorden and Gipsdalen groups from Lower Devonian to lowermost Upper Devonian rocks of the Andrée Land Group and Mimerdalen Subgroup during early Cenozoic Eurekan deformation in central Spitsbergen. Eurekan strain decoupling along these structures explains differential deformation between Lower Devonian to lowermost Upper Devonian rocks of the Andrée Land Group and/or Mimerdalen Subgroup and overlying uppermost Devonian-Permian sedimentary strata of the Billefjorden and Gipsdalen groups in central-northern Spitsbergen without requiring an episode of (Ellesmerian) contraction in the Late Devonian. Potential formation mechanisms for bedding-parallel décollements and thrusts include shortcut faulting and/or formation as a roof décollement in a fault-bend hanging wall (or ramp) anticline, as an imbricate fan, as an antiformal thrust stack, and/or as fault-propagation folds over reactivated or overprinted basement-seated faults. The interpretation of seismic data in Reindalspasset indicates that Devonian sedimentary rocks of the Andrée Land
\end{abstract}

Group and Mimerdalen Subgroup might be preserved east of the Billefjorden Fault Zone, suggesting that the Billefjorden Fault Zone did not accommodate reverse movement in the Late Devonian. Hence, the thrusting of Proterozoic basement rocks over Lower Devonian sedimentary rocks along the Balliolbreen Fault and fold structures within strata of the Andrée Land Group and Mimerdalen Subgroup in central Spitsbergen may be explained by a combination of down-east Carboniferous normal faulting with associated footwall rotation and exhumation, and subsequent top-west early Cenozoic Eurekan thrusting along the Billefjorden Fault Zone. Finally, the study shows that major east-dipping faults, like the Billefjorden Fault Zone, may consist of several discrete, unconnected (soft-linked and/or stepping) or, most probably, offset fault segments that were reactivated or overprinted to varying degrees during Eurekan deformation due to strain partitioning and/or decoupling along sub-orthogonal NNEdipping reverse faults.

\section{Introduction}

The main goal of this contribution is to examine the influence of strain decoupling and partitioning on deformation patterns within Devonian-Permian sedimentary successions in central Spitsbergen during the early Cenozoic Eurekan tectonic event. The impact of this event, though well studied in western Spitsbergen where it resulted in the formation of the West Spitsbergen Fold-and-Thrust Belt (Dallmann et al., 1988, 1993; Braathen et al., 1999) with multi- 
ple levels of detachment and décollement (Maher, 1984; Maher et al., 1986; Bergh et al., 2000), lacks detailed characterization in central Spitsbergen (Fig. 1a; see DataverseNO for high-resolution versions of all figures and supplements https://doi.org/10.18710/IIHGSH, Koehl, 2021b).

The study has potential implications for strain partitioning in rift systems and distal parts of fold-and-thrust belts. Notably, the study describes bedding-parallel décollement levels and imbricate link thrusts (McClay and Insley, 1986) arranged into gently dipping duplexes within weak sedimentary beds of the Andrée Land Group, Billefjorden Group, and Wordiekammen Formation, which were, thus far, not described, and it discusses their role in partially decoupling Eurekan deformation in late Paleozoic sedimentary successions. Potential formation mechanisms, such as shortcut faulting (Buiter and Pfiffner, 2003), and the influence of preexisting inherited structures (e.g., Billefjorden Fault Zone) are reviewed.

The identification of structures showing comparable geometries and kinematics (e.g., bedding-parallel décollements) within discrete stratigraphic units (e.g., coals and coaly shales of the Billefjorden Group) both on nearshore seismic data and onshore during structural fieldwork further validates the use of seismic interpretation in areas where extensive (glacial) erosion resulted in partial destruction and covering of outcrop transects with loose material, and where large portions of the outcrops available for field mapping are hardly accessible for detailed inspection because they are located on steep slopes and cliffs. The study also illustrates the complementarity between fieldwork, which provides detailed lithological and structural data, and seismic transects providing continuous transects through deformation belts and fault zones.

The study also briefly discusses implications for the Ellesmerian Orogeny, a poorly constrained short-lived episode of contractional deformation in the Late Devonian that presumably explains the juxtaposition of Proterozoic basement against Lower Devonian to lowermost Upper Devonian sedimentary strata of the Andrée Land Group and Mimerdalen Subgroup (Vogt, 1938; Harland et al., 1974; McCann, 2000; Piepjohn, 2000; Piepjohn et al., 2000; Piepjohn and Dallmann, 2014), and differential deformation between folded Devonian rocks of the Andrée Land Group and Mimerdalen Subgroup and poorly deformed rocks of the uppermost Devonian-Permian Billefjorden and Gipsdalen groups in Dickson Land in central Spitsbergen. Notably, the contribution shows that Eurekan deformation localized in weak, intensely deformed sedimentary units of the uppermost Devonian-Permian sedimentary rocks of the Billefjorden and Gipsdalen rocks; that Devonian sedimentary rocks of the Andrée Land Group are possibly preserved east of the Billefjorden Fault Zone; and, thus, that the Billefjorden Fault Zone most likely did not act as a reverse fault in the Late Devonian, and that juxtaposition of Proterozoic basement against Lower Devonian rocks in central Spitsbergen may be achieved through Carboniferous normal faulting and early Cenozoic Eurekan top-west thrusting. Hence, the study contributes to our understanding of both deformation partitioning in fold-and-thrust belts consisting of thick sedimentary successions and the extent of the Ellesmerian Orogeny in the Arctic, which presumably extends from Arctic Canada and northern Greenland to Spitsbergen.

Finally, the study has implications for the segmentation and linkage of rift-bounding faults with long-lived tectonic histories. Thus far, although segmentation of the Billefjorden Fault Zone was described (e.g., Bælum and Braathen, 2012), along-strike geometrical and kinematics variations along the Billefjorden Fault Zone have been poorly addressed and tentatively attributed to the complex tectonic history of this fault. The present study further discusses the significant along-strike variations in geometry and kinematics as well as the extent and potential segmentation of the Billefjorden Fault Zone in conjunction with a new trend of NNE-dipping faults striking suborthogonal to the main $\mathrm{N}-\mathrm{S}$-trending structural grain in the study area. The role of these suborthogonal faults in Eurekan strain partitioning is briefly discussed.

\section{Geological setting}

\subsection{Caledonian Orogeny}

Spitsbergen is composed of three terranes that started assembling during the late Cambrian-Silurian Caledonian Orogeny and were juxtaposed against one another by $\mathrm{N}-\mathrm{S}$-striking crustal faults like the Billefjorden Fault Zone (Harland and Wright, 1979; Ohta et al., 1989, 1995; Gee and Page, 1994). Caledonian deformation was accompanied by tectonothermal events with high-grade (eclogite and blueschist) metamorphism from mid-Cambrian to late Silurian times that occurred during subduction and closure of the Iapetus Ocean and that are partly preserved in northwestern (Ohta et al., 1989) and western Spitsbergen (Horsfield, 1972; Kośmińska et al., 2014).

Caledonian grain in western, northwestern, central, and eastern Spitsbergen forms major, gently plunging, $\mathrm{N}-\mathrm{S}-$ trending folds and thrust stacks with well-developed foliation. An example is the Atomfjella Antiform in Ny-Friesland (Fig. 1b), an antiformal thrust stack that consists of a succession of nappes composed of Proterozoic granite and metasedimentary rocks separated by west-verging (Flood et al., 1969; Balashov et al., 1993; Witt-Nilsson et al., 1998; Johansson and Gee, 1999; Johansson et al., 2004, 2005) and/or top-east thrusts (Manby and Michalski, 2014). 


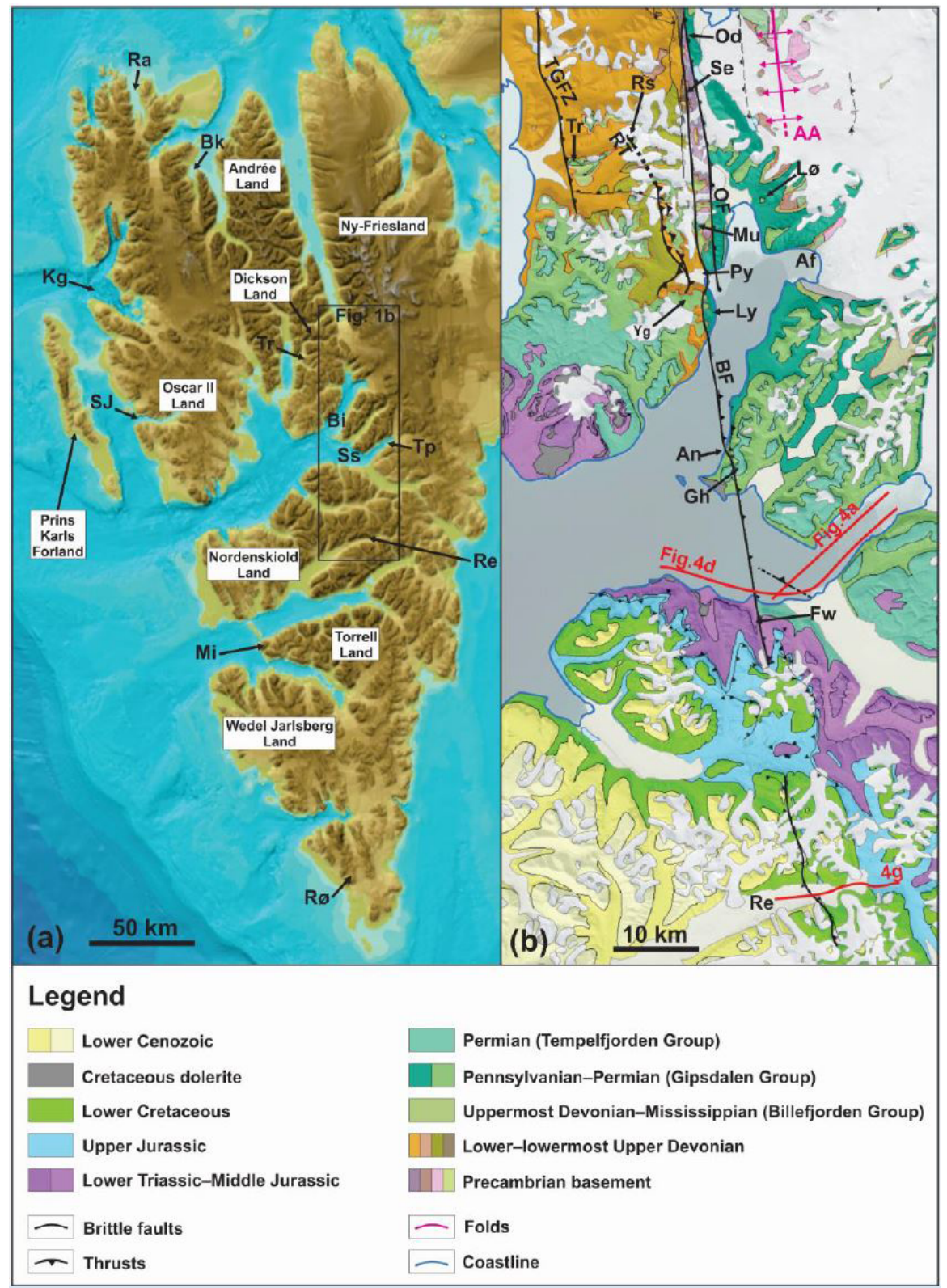

Figure 1. (a) Topographic-bathymetric map around Spitsbergen modified after Jakobsson et al. (2012). Abbreviations - Bi: Billefjorden; Bk: Bockfjorden; Kg: Kongsfjorden; Mi: Midterhuken; Ra: Raudfjorden; Re: Reindalspasset; Rø: Røkensåta; Ss: Sassenfjorden; SJ: St-Jonsfjorden; Tp: Tempelfjorden; Tr: Triungen. (b) Geological map modified from svalbardkartet.npolar.no showing the main tectonostratigraphic units and structures in the study area in central Spitsbergen. Abbreviations - AA: Atomfjella Antiform; Af: Adolfbukta; An: Anservika; BF: Balliolbreen Fault; Fw: Flowerdalen; Gh: Gipshuken; Ly: Lykteneset; Lø: Løvehovden-Hultberget; Mu: Mumien; Od: Odellfjellet; OF: Odellfjellet Fault; Py: Pyramiden; Re: Reindalspasset; Rs: Robertsonbreen; RT: Robertsonbreen thrust; Se: Sentinelfjellet; TGFZ: Triungen-Grønhorgdalen Fault Zone; Tr: Triungen; Yg: Yggdrasilkampen.

\subsection{Devonian late-post-orogenic collapse}

In the Early Devonian, late-post-Caledonian gravitational collapse initiated (Chorowicz, 1992; Roy, 2007, 2009¹) leading to the deposition of (Old Red Sandstone) basins sev-

\footnotetext{
${ }^{1}$ The 2009 thesis also includes an unpublished manuscript submitted to the Norwegian Journal of Geology.
}

eral kilometers thick throughout Spitsbergen (Birkenmajer and Turnau, 1962; Harland et al., 1974; Manby and Lyberis, 1992; Manby et al., 1994; Dallmann and Piepjohn, 2020) and emplacement of late-orogenic plutons in northwestern, central, and eastern Spitsbergen (Hamilton et al., 1962; Gayer et al., 1966; Ohta et al., 2002; Myhre et al., 2008). 
In northern Spitsbergen, Devonian sedimentary rocks of the Siktefjellet, Red Bay, and Andrée Land groups (Gee and Moody-Stuart, 1966; Friend et al., 1966; Friend and MoodyStuart, 1972; Murascov and Mokin, 1979; Friend et al., 1997; Fig. 2) deposited during extension and subsidence along $\mathrm{N}-$ S-striking normal faults, forming west-tilted grabens and/or half-grabens, e.g., in Raudfjorden, Bockfjorden (Manby and Lyberis, 1992; Manby et al., 1994), Andrée Land, and Kota (Roy, 2007, 2009; Fig. 1a). However, other works argue that Devonian sedimentary deposits of the Andrée Land Group and Mimerdalen Subgroup (Fig. 2) in Svalbard deposited along low-angle, post-Caledonian detachments that accommodated large amounts of top-east, normal movement (e.g., the Woodfjorden detachment) and are associated with synkinematic east-verging folds (Roy, 2007, 2009). In addition, recent studies show that basement ridges, e.g., the Bockfjorden Anticline in northwestern Spitsbergen, may have exhumed as core complexes along low-angle extensional detachments (e.g., the Keisarhjelmen detachment), and $\mathrm{K}-\mathrm{Ar}$ geochronology suggests that exhumation occurred from late Silurian to Late Devonian times (Braathen et al., 2018).

\subsection{Ellesmerian Orogeny}

Ellesmerian deformation is thought to have initiated in the Late Devonian-Early Mississippian, possibly in the Late Frasnian-Famennian (Vigran, 1964; Allen, 1965, 1973; Pčelina et al., 1986; Brinkmann, 1997; Schweitzer, 1999; Piepjohn et al., 2000), and was presumably recorded by the deposition of coarse-grained sedimentary rocks of the Mimerdalen Subgroup (Planteryggen and Plantekløfta formations; Piepjohn and Dallmann, 2014). However, recent fossil and spore analysis suggest an early Frasnian (ca. $380 \mathrm{Ma}$ ) age for these stratigraphic units (Berry and Marshall, 2015). Deformation is believed to have stopped prior to the deposition of middle-late Famennian-Mississippian (Scheibner et al., 2012; Lindemann et al., 2013; Marshall et al., 2015; Würtzen et al., 2019; Gilda Lopes, personal communication, 2019) sedimentary rocks of the Billefjorden Group (Vogt, 1938; Piepjohn, 2000). Previous works also suggested that hundreds-thousands of kilometer-scale strikeslip movement along N-S-striking faults, e.g., Billefjorden Fault Zone, finalized the accretion of basement terranes constituting the Svalbard Archipelago (Harland et al., 1974; Harland and Wright, 1979; Ohta et al., 1989), while more recent studies argue for limited amounts of strike-slip movement (McCann, 2000; Piepjohn, 2000).

In Pyramiden, in Dickson Land (northern-central Spitsbergen; Fig. 1b), Proterozoic basement rocks were thrust top-west onto Lower Devonian sedimentary rocks of the Wood Bay Formation along the Balliolbreen Fault (Harland et al., 1974; Piepjohn, 2000; Bergh et al., 2011) in Late Devonian times, and presumably undeformed uppermost Devonian-Mississippian clastic and coal-bearing sedimentary deposits of the Billefjorden Group overlie folded Lower
Devonian to lowermost Upper Devonian metasedimentary rocks that were involved in Ellesmerian deformation. In Triungen (Fig. 1a-b), folded-gently dipping Lower Devonian rocks of the Wood Bay Formation are juxtaposed against flatlying, undeformed, uppermost Devonian-Permian strata of the Billefjorden Group and Wordiekammen Formation along the Triungen-Grønhorgdalen Fault Zone (McCann and Dallmann, 1996). In Sentinelfjellet and Odellfjellet (Fig. 1b), the Balliolbreen Fault thrust Proterozoic basement rocks in the hanging wall over Devonian sedimentary rocks of the Andrée Land Group and Mimerdalen Subgroup in the footwall and is thought to be unconformably overlain by undeformed, uppermost Devonian-Mississippian sedimentary rocks of the Billefjorden Group, thus suggesting Late Devonian top-west thrusting (Friend and Moody-Stuart, 1972; Harland et al., 1974; Lamar et al., 1986).

\subsection{Carboniferous basins}

In Carboniferous times, ENE-WSW extension formed narrow (from kilometers to tens of kilometers wide) N-S- to NW-SE-trending troughs, e.g., Billefjorden Trough (Maher, 1996; McCann and Dallmann, 1996; Braathen et al., 2011), bounded by major faults such as the Billefjorden Fault Zone (Harland et al., 1974), which was reactivated as a normal fault from Odellfjellet in the north to Reindalspasset in the south (Bælum and Braathen, 2012; Fig. 1a-b).

Shortly after the end of Ellesmerian deformation, partly eroded Devonian sedimentary rocks of the Andree Land Group and Mimerdalen Subgroup were covered by uppermost Devonian-Mississippian (Marshall et al., 2015), fluvial, and coal- and clastic-rich deposits of the Billefjorden Group (Cutbill and Challinor, 1965; Cutbill et al., 1976; Aakvik, 1981; Gjelberg, 1981, 1984; Fig. 2). These are divided into the Hørbyebreen and Mumien formations, which are composed of the Triungen and Hoelbreen and the Sporehøgda and Birger Johnsonfjellet members respectively. The Triungen and Sporehøgda members dominantly consist of clastics whereas the Hoelbreen and Birger Johnsonfjellet members are composed of coal seams and coaly shales (Cutbill and Challinor, 1965; Cutbill et al., 1976; Aakvik, 1981; Gjelberg and Steel, 1981; Gjelberg, 1984; Fig. 2).

These deposits are found in Arctic areas stretching from the Barents Sea (Bugge et al., 1995; Larssen et al., 2002) to Arctic Canada (Emma Fiord Formation; Davies and Nassichuck, 1988) and were presumably deposited during a period of tectonic quiescence (Johannessen and Steel, 1992; Braathen et al., 2011; Smyrak-Sikora et al., 2018), though a syn-tectonic deposition was also proposed for these rocks in Arctic Canada (Beauchamp et al., 2018), the Barents Sea (Koehl et al., 2018), Bjørnøya (Gjelberg, 1981), and in Spitsbergen in the northern part of the Billefjorden Trough (Koehl and Muñoz-Barrera, 2018).

In the Pennsylvanian, fluvial to shallow marine sedimentary strata of the Gipsdalen Group were deposited in subsid- 


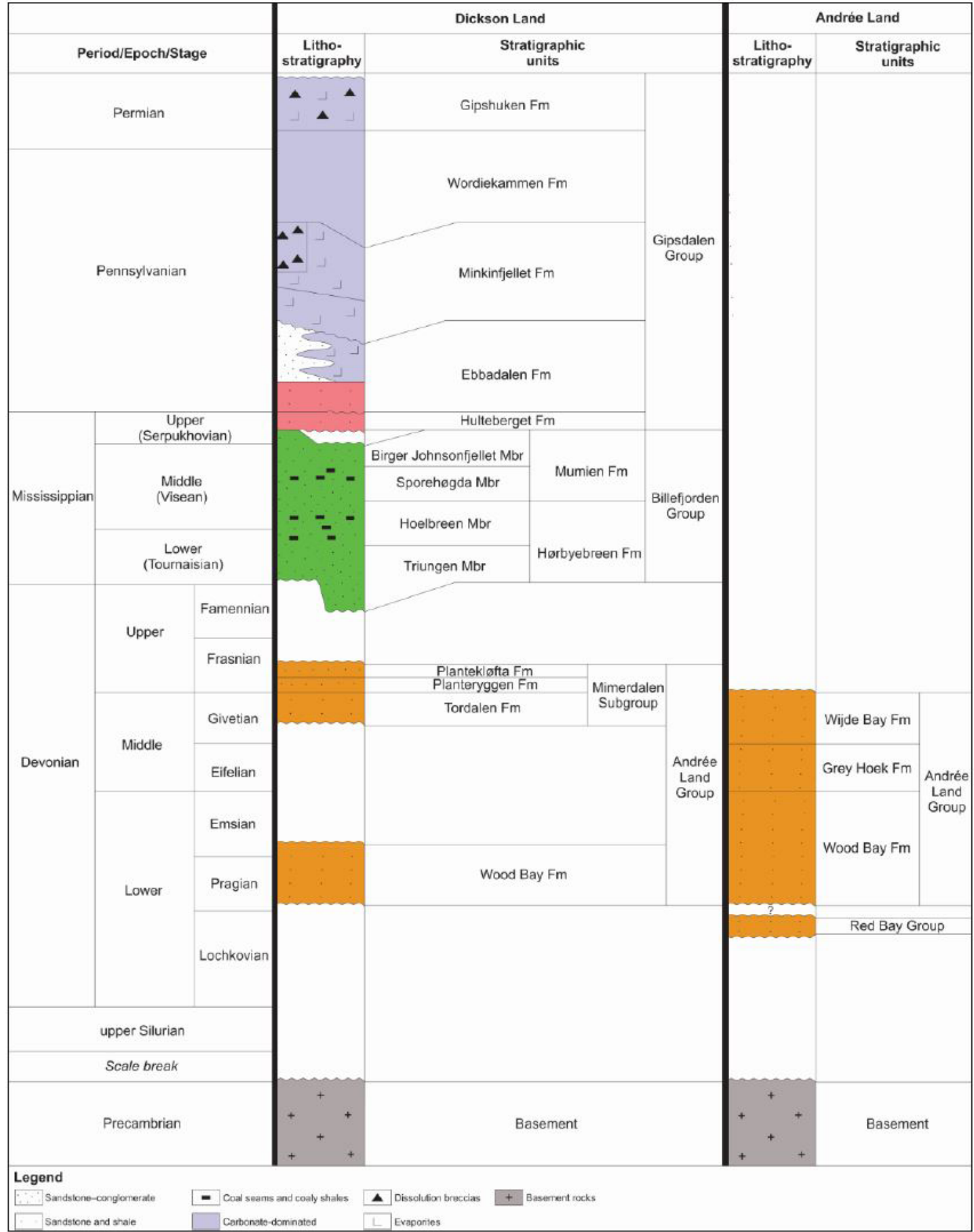

Figure 2. Stratigraphic chart for central (Dickson Land) and northern (Andrée Land) Spitsbergen.

ing basins. These are divided into the Hultberget, Ebbadalen, Minkinfjellet, Wordiekammen, and Gipshuken formations in central Spitsbergen (Cutbill and Challinor, 1965; Johannessen, 1980; Gjelberg and Steel, 1981; Johannessen and Steel, 1992; Braathen et al., 2011; Smyrak-Sikora et al., 2018), all of which range from late Serpukhovian to earliest Permian in age (Fig. 2).
Sedimentary strata of the Gipsdalen Group are mostly composed of clastic, carbonate and evaporitic deposits and karst breccia and represent the thickest sedimentary succession in the Billefjorden Trough (McWhae, 1953; Cutbill and Challinor, 1965; Holliday and Cutbill, 1972; Johannessen, 1980; Lønøy, 1995; Fig. 2). The deposition of sedimentary strata of the Hultberget, Ebbadalen, and Minkinfjellet forma- 
tions was accompanied by kilometer-scale normal displacement along N-S-striking faults like the Billefjorden Fault Zone, whereas the Wordiekammen and Gipshuken formations were deposited during minor tectonic activity (Gjelberg and Steel, 1981; Fedorowski, 1982; Braathen et al., 2011; Smyrak-Sikora et al., 2018).

\subsection{Eurekan deformation}

In the Paleocene (ca. $62 \mathrm{Ma}$ ), Eurekan deformation initiated in western Spitsbergen due to the opening of the Labrador Sea and Baffin Bay between Canada and Greenland (Chalmers and Pulvertaft, 2001; Oakey and Chalmers, 2012) and resulted in the formation of the West Spitsbergen Foldand-Thrust Belt between Kongsfjorden and Sørkapp (Harland, 1969; Lowell, 1972; Harland and Horsfield, 1974; Maher et al., 1986; Dallmann et al., 1988, 1993; Andresen et al., 1994; Bergh and Grogan, 2003) and formation of a foreland basin, the Tertiary Central Basin, in central Spitsbergen (Larsen, 1988; Petersen et al., 2016). Eurekan thrusts and folds in Spitsbergen dominantly strike and trend NNW-SSE (Harland and Horsfield, 1974; Bergh and Andresen, 1990; Dallmann et al., 1993; Bergh et al., 2011; Blinova et al., 2012), except in Kongsfjorden (Fig. 1a) where they strike and trend WNW-ESE (Bergh and Andresen, 1990; Bergh et al., 2000; Saalmann and Thiedig, 2000, 2001; Piepjohn et al., 2001). Early Cenozoic thrusts in western Spitsbergen commonly form décollements in shaly beds, e.g., in Triassic shales in Midterhuken (Maher, 1984; Maher et al., 1986; Fig. 1a). In central-eastern Spitsbergen, major N-S-striking brittle faults like the Billefjorden Fault Zone were partly reactivated by Eurekan deformation in Flowerdalen (Harland et al., 1974; Haremo et al., 1990; Haremo and Andresen, 1992; Fig. 1b) and Reindalspasset (Bælum and Braathen, 2012) in the south but were apparently unaffected in northern areas like Sentinelfjellet (see location in Fig. 1b) where uppermost Devonian-Mississippian strata seem to unconformably lie over the fault (Harland et al., 1974).

\section{Methods}

The present contribution uses strike and dip measurements of bedding and fracture surfaces in Devonian-Mississippian sandstone, coals, and coaly shales of the Billefjorden Group collected in summer 2016 in Pyramiden (Fig. 1b). These were used to determine the state of deformation of the various lithological units of the Billefjorden Group, to infer the presence of major faults, and to assess fault kinematics. Unfortunately only a few slickensides of poor quality were recorded and these are not presented in the present study.

The study also uses microscopic analysis of fault rocks and sedimentary rocks adjacent to brittle faults as a confirmation tool (included in Fig. S1 in the Supplement). Thin sections were cut perpendicular to potential brittle faults in the field to better observe brittle deformation and offset. Cohesive fault rock was exclusively encountered in a gully below the mine entrance in Pyramiden, along the potential field occurrence of the Balliolbreen Fault.

Seismic data in nearshore fjords in central Spitsbergen are from the Norwegian Petroleum Directorate and uninterpreted seismic lines are provided in Fig. S2. Seismic interpretation was tied to data from exploration well 7816/12-1 in Reindalspasset (Fig. 1a-b; Eide et al., 1991), and time-depth conversion of well data is based on checkshots from Equinor and Store Norske Spitsbergen Kulkompani. The well penetrated late Paleozoic-Mesozoic sedimentary rocks and ends at a depth of $2261 \mathrm{~m}$ with $54 \mathrm{~m}$ of uppermost DevonianMississippian strata of the Billefjorden Group.

\section{Results and interpretations}

\subsection{Field and petrological data}

\subsubsection{Pyramiden}

In Pyramiden, a steeply east-dipping, N-S-striking brittle fault crops out in a gully below the entrance of the Russian coal mine (Fig. 3). This fault is located half-way to the mine in the gully and crosscuts steeply east-dipping Lower Devonian sedimentary rocks of the Wood Bay Formation (Fig. 2), which are incorporated into a large fold structure with Devonian bedding surfaces locally overturned to the east (Figs. 3, 4a, and S3). The fault shows meter-thick lenses of cataclastic fault rock (Fig. S1). Devonian sedimentary rocks are dominated by poorly deformed quartz crystals showing undulose extinction and limited recrystallization (Fig. S1), whereas cataclastic fault rock shows distributed fractures with little (centimeter-scale) to no displacement.

There is no trace of Proterozoic basement rocks in this area although field studies and geological maps suggest that Proterozoic basement rock was thrust over Lower Devonian strata along the Balliolbreen Fault (McCann, 1993; McCann and Dallmann, 1996; Piepjohn et al., 1997; Dallmann et al., 1999, 2004; Bergh et al., 2011; https://svalbardkartet.npolar. no, last access: 6 May 2021). Sample preparation for thin sectioning actually proved problematic for Devonian sedimentary rocks (quartzitic sandstone) located in the hanging wall of the presumed fault, which resulted in misleading thick sections showing quartz crystals resembling pyroxenes (Fig. S1). Thus, it is more likely that earlier maps showing exclusively Devonian-Mississippian sedimentary rocks of the Wood Bay Formation and Billefjorden Group (Fig. 2) below the mine entrance by Harland et al. (1974), Aakvik (1981), Lamar et al. (1986), and Trust Arktikugol (unpublished data; Alexander Sirotkin, personal communication, 2019) are correct.

Farther up the gully, a 1-2 m thick succession of interbedded sandstone and coal is juxtaposed against steeply east- 


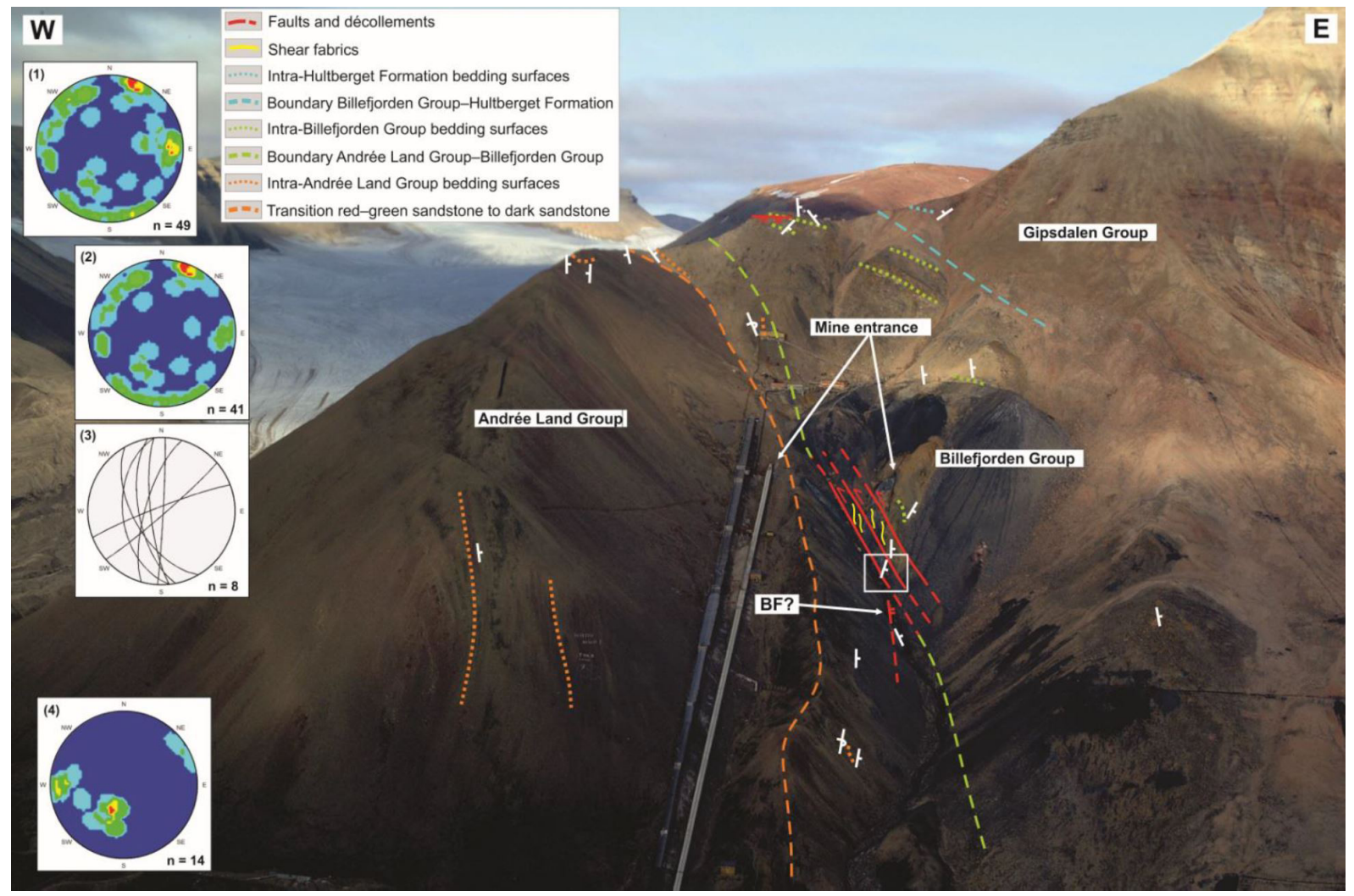

Figure 3. Aerial photograph of the Pyramiden coal mine locality showing intensely folded (dotted orange lines) Lower Devonian rocks in the west juxtaposed against clastic- and coal-rich uppermost Devonian-Mississippian sedimentary rocks of the Billefjorden Group, which are overlain by Pennsylvanian-lower Permian strata of the Gipsdalen Group in the east. Dashed lines represent lithostratigraphic transitions. Dotted lines represent bedding surfaces as seen in the photograph, whereas white symbols indicate a bedding trend and dip in map view (see Fig. 4a). Note the Z-shaped fabrics of uppermost Devonian-Mississippian sedimentary strata (yellow lines) along potential beddingparallel décollements (red lines) near the boundary between Lower Devonian and uppermost Devonian-Mississippian sedimentary rocks. The white frame shows the location of Fig. 4b. Lower-hemisphere Schmidt stereonets show (1) contoured poles of fracture surfaces in the uppermost Devonian-Mississippian Billefjorden Group (red indicates high and blue low density), (2) contoured poles of fracture surfaces within sandstone units of the Billefjorden Group, (3) great circles of fracture surfaces within coaly shale- and coal-bearing units of the Billefjorden Group, and (4) contoured poles of fracture surfaces in Lower Devonian rocks. Photo by Åsle Strøm.

dipping Lower Devonian strata to the west and overlain by a thick layer (of at least $3 \mathrm{~m}$ ) of uppermost DevonianMississippian coals of the Billefjorden Group that shows phyllitic shear fabrics (Figs. 3, 4b and S4). The presence of abundant coal suggests that this $1-2 \mathrm{~m}$ thick unit is part of the Billefjorden Group as well (Fig. 2). Bedding surfaces within the 1-2 $\mathrm{m}$ thick succession dip gently-steeply to the east (Fig. 4a), display sigmoidal geometries with Z-like shapes, and terminate abruptly against the $3 \mathrm{~m}$ thick layer of uppermost Devonian-Mississippian phyllitic coal upwards and against Lower Devonian rocks downwards (dashed yellow lines in Fig. 4b). In addition, coaly shales within this succession display phyllitic fabrics similar to those observed within overlying coals and seem to form repeated successions of alternating beds of sandstone and coaly shale truncated by steeply east-dipping sigmoidal fault surfaces (thin dashed red lines in Fig. 4b). The Z-like sigmoidal shape of bedding sur- faces, phyllitic shear fabrics of the coaly shales, and possible repetitions of the succession suggest that the steeply east-dipping, sigmoidal faults crosscutting the succession are imbricate thrust faults (stereonet 3 in Fig. 3), i.e., possible link thrusts (McClay and Insley, 1986), which accommodated top-west to top-WNW movements. The truncation of sandstone-coaly shale beds upwards and downwards, the abrupt transition (partly covered by scree) with underlying Lower Devonian rocks and overlying uppermost DevonianMississippian coals, and Z-shaped phyllitic shear fabrics within overlying coals suggest that the sandstone-coalyshale succession is bounded by moderate-low-angle, eastdipping floor and roof thrusts (McClay, 1992) with top-west to top-WNW sense of shear. In cross section, the interaction of intra-succession, steeply east-dipping link thrusts and inter-succession, moderate-low-angle floor and roof thrusts defines an east-dipping duplex structure (Boyer and Elliott, 


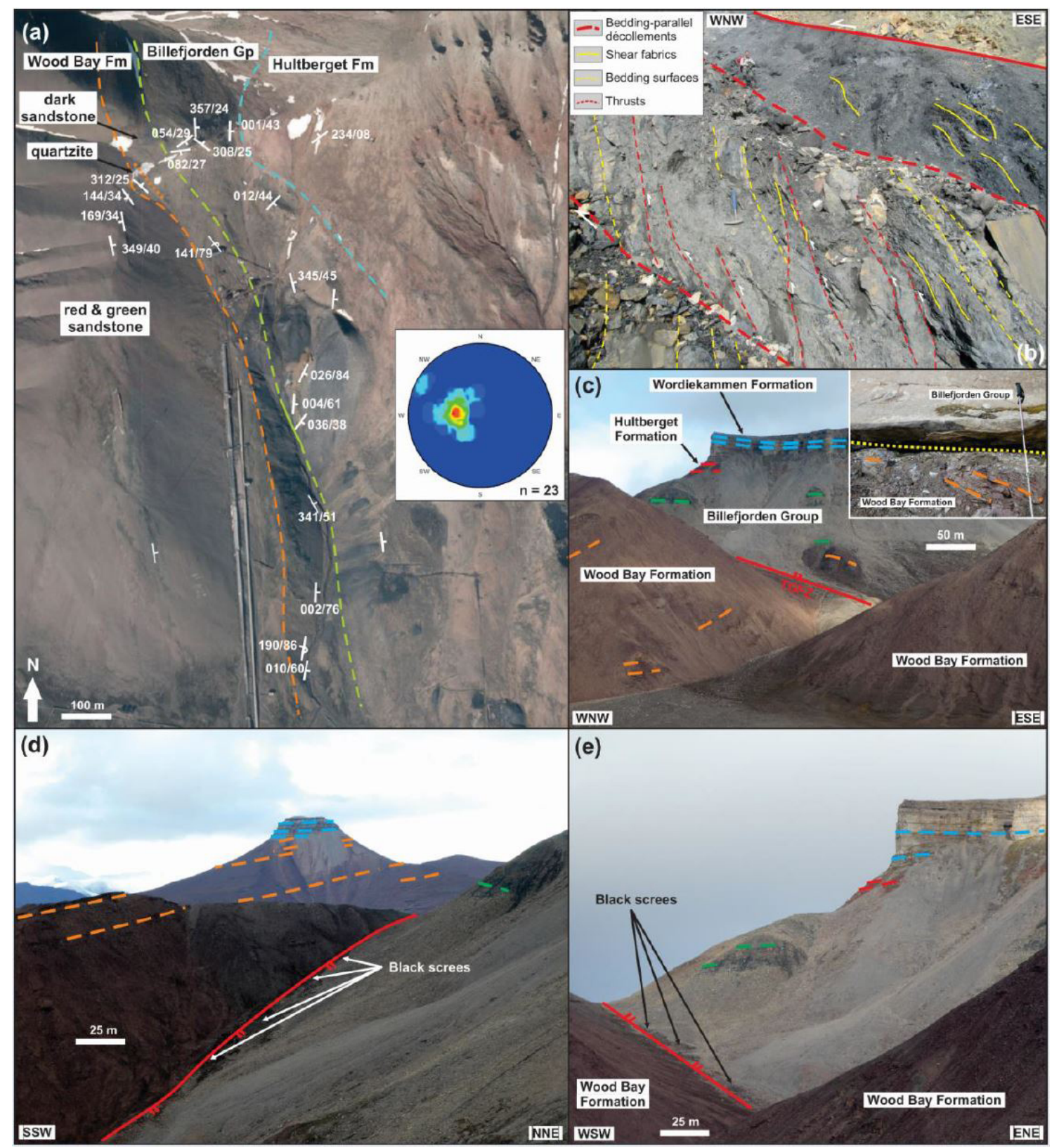

Figure 4. (a) Satellite photograph of the Pyramiden locality (Fig. 3) from https://toposvalbard.npolar.no (last access: 6 May 2021). See legend in Fig. 3. Bedding surface measurements are shown in white. The lower-hemisphere Schmidt stereonet shows bedding surface measurements in the Billefjorden Group as contoured poles (red indicates high and blue low density). (b) Field photograph of the base of uppermost Devonian-Mississippian, coaly shale- and coal-rich sedimentary rocks of the Billefjorden Group below the mine entrance in Pyramiden. The photo shows gently east-dipping stratigraphic unit boundaries that localized the formation of bedding-parallel décollements (thick red and thick dashed red lines). Within individual units, coal displays phyllitic, Z-shaped shear fabrics (yellow lines) parallel-subparallel to steeply east-dipping, intra-unit bedding surfaces (dashed yellow lines) that are truncated by subparallel, steeply east-dipping thrusts (thin dashed red lines). See the blue hammer $(\mathrm{ca} .40 \mathrm{~cm})$ in the foreground and person $(\mathrm{ca} .1 .75 \mathrm{~m})$ in the background for scale. See Fig. S4 for uninterpreted photograph. Location is shown in Fig. 3. (c) Field photograph showing gently south-dipping Lower Devonian rocks of the Wood Bay Formation unconformably overlain by flat-lying strata of the Billefjorden Group (dashed green bedding surfaces), Hultberget Formation (dashed red bedding surfaces), and Wordiekammen Formation (dashed blue bedding surfaces) in the hanging wall of the TriungenGrønhorgdalen Fault Zone in Triungen (see Fig. 1b for location). The upper right inset displays the angular unconformity (dotted yellow line) between gently south-dipping (tilted?) Lower Devonian sedimentary rocks of the Wood Bay Formation (bedding surfaces in dashed orange) and overlying flat-lying strata of the Billefjorden Group. (d) Field photograph of the inferred location of the Triungen-Grønhorgdalen Fault Zone in Triungen showing that the fault trace is not exposed and is covered by local black scree probably belonging to uppermost DevonianMississippian coals of the Billefjorden Group. View is towards the west-northwest. (e) Same as (d) with view towards the north. 
1982) of imbricate thrusts bounded upwards and downwards by potential décollements and/or detachments parallel to original (i.e., prior to deformation) bedding surfaces (e.g., thick red lines showing the transition from interbedded coaly shales and sandstone to coal, and from coal to sandstone in Fig. 4b). The nomenclature of hindward- or forward-dipping duplexes of Boyer and Elliott (1982) does not apply here since the foreland of the West Spitsbergen Fold-and-Thrust Belt (Tertiary Central Basin) is located southeast of Pyramiden. Thus, the term "backward" is used to describe the east-dipping character of the duplexes, i.e., oppositely to the inferred transport direction.

Above the mine entrance, sedimentary rocks of the Billefjorden Group are dominated by yellow sandstone that are crosscut by dominant WNW-ESE-striking fractures and subsidiary N-S- and ENE-WSW-striking fractures (stereonets 1 and 2 in Fig. 3) showing oblique-slip kinematics. Poorly preserved slickenside lineations did not yield any information on relative displacement between footwall and hanging wall. In the west, dark sandstone and quartzite crop out and contain fossil wood, which are probably Lower Devonian in age. The contact between the Lower (-lowermost Upper?) Devonian dark sandstone and uppermost DevonianMississippian yellow sandstone of the Billefjorden Group and intra-Devonian lithological contacts (e.g., between Devonian quartzite and dark sandstone; Fig. 4a), although partly covered by scree and/or mostly made of loose blocks, do not appear to be faulted or tectonized and trend approximately WNW-ESE to NW-SE as bedding surfaces appear to change from moderately-steeply east-dipping below the mine entrance to gently NNE-dipping above the mine entrance (Figs. 3 and 4a), i.e., parallel to the dominant fault trend in both uppermost Devonian-Mississippian (stereonet 1 in Fig. 3) and Lower (-lowermost Upper?) Devonian rocks (stereonet 4 in Fig. 3).

It is worth noting that most outcrops of uppermost Devonian-Mississippian strata in this part of the study area trend E-W to WNW-ESE. Thus, the dominance of WNWESE-striking faults is unlikely the result of measurements flawed by a preferential outcrop trend, since E-W- to WNWESE-trending outcrops would rather favor identification and measurement of $\mathrm{N}-\mathrm{S}$-striking faults.

A possible interpretation of outcrops and structures in Pyramiden (Fig. 1b) is that the subvertical, N-S-striking brittle fault within steeply east-dipping Lower Devonian strata in the gully below the coal mine entrance (Figs. 3 and 4a) represents the Balliolbreen Fault segment of the Billefjorden Fault Zone, and that low-angle roof or floor thrusts between Lower (-lowermost Upper?) Devonian rocks and the overlying succession of uppermost Devonian-Mississippian sandstone, coaly shale, and coal (Fig. 4b) correspond to the upward-flattening continuation of this fault. However, no fault was observed between Lower (-lowermost Upper?) Devonian rocks of the Andrée Land Group (and Mimerdalen Subgroup) and sandstones of the Billefjorden Group above the mine, and lithological and stratigraphic contacts there display significantly different trends (WNW-ESE to NWSE; Fig. 4a).

\subsubsection{Triungen}

Fieldwork in Triungen (see location in Fig. 1a-b) shows that the Triungen-Grønhorgdalen Fault Zone (McCann and Dallmann, 1996) and the contact between Lower Devonian of the Wood Bay Formation and overlying uppermost DevonianMississippian sedimentary rocks of the Billefjorden Group along the fault are largely covered by dark scree (Fig. 4ce). In the hanging wall though, Lower Devonian sedimentary strata are moderately tilted to the south and define an angular unconformity with overlying, flat-lying strata of the Billefjorden Group (Fig. 4c). Based on the presence of thick, flat-lying, coal-rich strata in the lower part of the Billefjorden Group overlying Lower Devonian sedimentary strata in the hanging wall of the fault, the dark scree along the fault trace (Fig. 4d-e) are interpreted to represent uppermost Devonian-Mississippian coals-coaly shales that might have been dragged along the Triungen-Grønhorgdalen Fault Zone during tectonic movements.

\subsection{Seismic data}

\subsubsection{Seismic units and stratigraphy}

In seismic sections, Precambrian-Caledonian basement rocks commonly show chaotic reflections, most likely arising from their complex tectonic history (e.g., Caledonian folding, shearing, and thrusting and post-Caledonian extensional and contractional overprints), and subparallel reflections, possibly corresponding to seismic artifacts (e.g., multiples; Fig. 5a-g; see DataverseNO for high-resolution versions of all figures and supplements; https://doi.org/10.18710/IIHGSH, Koehl, 2021b).

Potential Devonian rocks of the Andrée Land Group in Reindalspasset (Figs. 1a-b and 2) are characterized by partly disrupted, semi-continuous, sub-parallel to chaotic, moderate- to low-amplitude seismic reflections (Fig. $5 \mathrm{~g}$ ). The moderate- to low-amplitude character of internal seismic reflections within this seismic unit suggests that it is made up of relatively homogeneous deposits with minor lithological variations. Thus, Devonian rocks in Reindalspasset are interpreted to consist of thick successions of medium- to fine-grained sedimentary rocks such as siltstone and shales, possibly of the Lower Devonian Wood Bay (or time-equivalent Marietoppen Formation in southern Spitsbergen) and/or Middle Devonian Grey Hoek and/or Wijde Bay formations.

Uppermost Devonian-Mississippian sedimentary rocks (Fig. 2) are characterized by high-amplitude seismic reflections that are most likely the product of acoustic impedance contrast between low-density coal seams interbedded with 

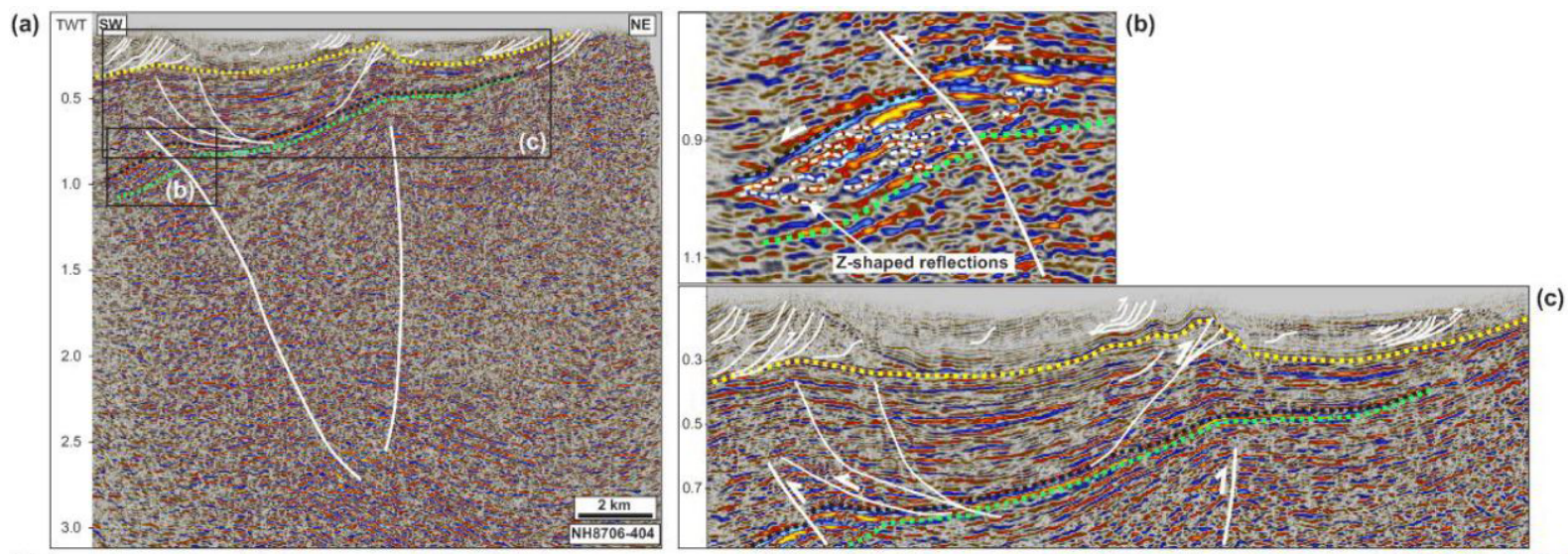

(d)
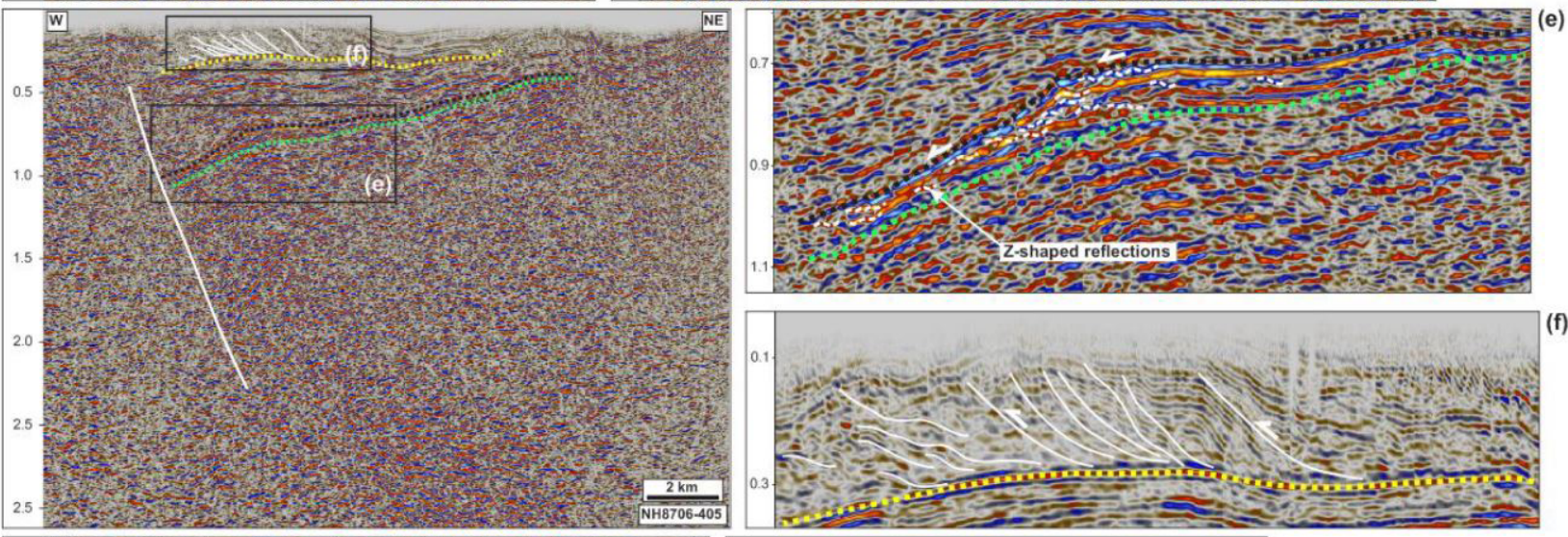

(g)
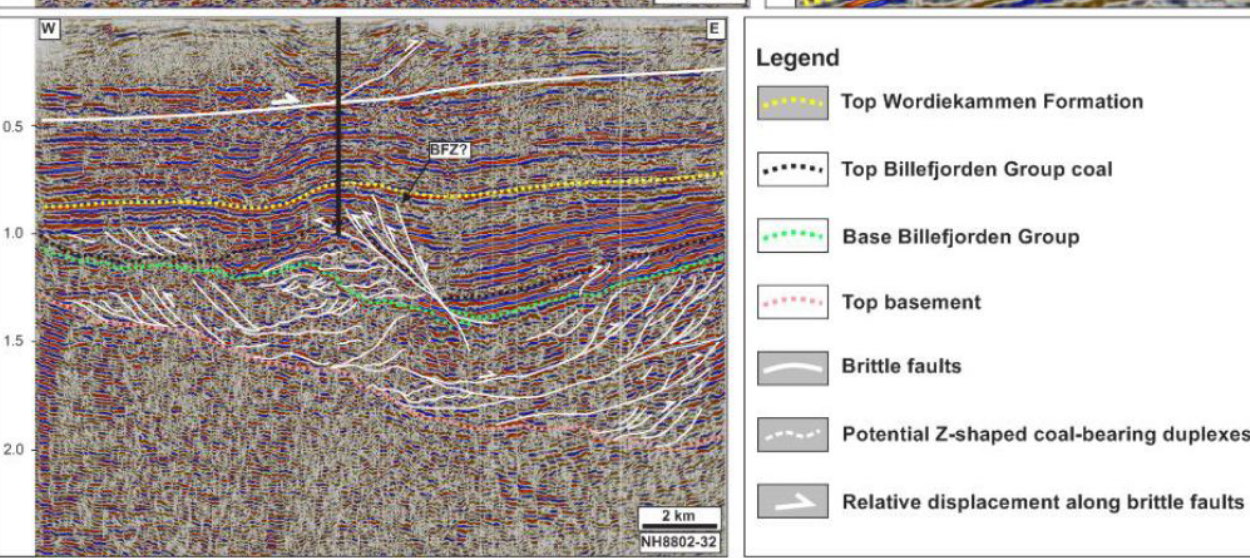

Figure 5. Seismic sections in two-way time (TWT) and associated zoomed-in portions in Saassenfjorden-Tempelfjorden (a-f) and Reindalspasset (g). See Fig. 1 b for locations. (a) NE-SW-trending section showing minor reverse offset and fault-propagation folding in thickened uppermost Devonian-Mississippian sedimentary rocks along WNW-ESE- to NW-SE-striking, deep-seated basement faults, and Eurekan thrusts in overlying Pennsylvanian-Permian strata. (b) Close-up of SW-verging, coal-bearing duplexes acting as top-SW Eurekan décollements in thickened, uppermost Devonian-Mississippian sedimentary deposits. (c) Close-up of NW-SE-striking Eurekan thrusts that flatten into décollements within uppermost Devonian-Mississippian coals and at the top of the Wordiekammen Formation. (d) NE-west-trending, arch-shaped section showing the potential continuation of the Billefjorden Fault Zone bounding thick uppermost Devonian-Permian sedimentary deposits and top-west Eurekan thrusts within lower Permian rocks. (e) Close-up of coal-bearing duplexes in uppermost DevonianMississippian sedimentary strata indicating top-west early Cenozoic movement. (f) Close-up of Eurekan thrusts flattening into a décollement near the top of the Wordiekammen Formation. (g) West-east-trending section showing a top-east Eurekan detachment in Mesozoic sedimentary rocks and a broad anticline in Devonian-Permian strata. Shale-rich Devonian-Mississippian sedimentary strata thicken into the anticline whereas Pennsylvanian-Permian sedimentary rocks thicken away from the anticline. The former are truncated by numerous early Cenozoic Eurekan thrusts arranged into duplex-like structures that flatten into intra-Devonian-Mississippian décollements. Note that the thick vertical black line represents the location of exploration well 7816/12-1 (total depth: 2261 m; Eide et al., 1991). Abbreviation - BFZ: Billefjorden Fault Zone. 
clastic deposits. Such a seismic facies is relatively common for uppermost Devonian-Mississippian sedimentary rocks in the Norwegian Barents Sea (Koehl et al., 2018; Tonstad, 2018). In Reindalspasset, uppermost DevonianMississippian, phyllitic, coal-rich deposits of the Billefjorden Group were penetrated by exploration well 7816/12-1 at a depth of $2261 \mathrm{~m}$ (Eide et al., 1991), which corresponds to a time of $0.96 \mathrm{~s}$ (TWT) when time-converted (Fig. 5g).

Pennsylvanian-Permian sedimentary strata of the Gipsdalen Group (Fig. 2) are mostly composed of packages of subparallel low- to moderate-amplitude seismic reflections separated by discrete, moderate- to high-amplitude reflections. The Hultberget and Ebbadalen formations dominantly show partly disrupted, subparallel reflections possibly representing medium- to fine-grained sedimentary strata (e.g., of the Trikolorfjellet Member) that, in places, alternate with chaotic seismic facies probably characterizing coarsegrained sedimentary deposits (e.g., of the Odellfjellet and/or Ebbaelva members; Johannessen, 1980; Johannessen and Steel, 1992; Braathen et al., 2011; Smyrak-Sikora et al., 2018). The Minkinfjellet and Wordiekammen formations are dominated by a thick package of sub-parallel, moderate- to low-amplitude seismic reflections mostly representing carbonate and gypsum deposits (Fig. 5). The top reflection of the Wordiekammen Formation is characterized by high amplitude and is relatively easy to trace throughout the study area (Fig. 5). Finally, the Gipshuken Formation displays chaotic to subhorizontal and subparallel low-amplitude seismic reflections (Fig. 5). The Wordiekammen and Gipshuken formations are easily identified on seismic data because they crop out at sea level along the northern shore of Sassenfjorden and Tempelfjorden and, hence, can be directly tied to onshore geology (Dallmann et al., 2004, 2009; Dallmann, 2015). Mesozoic sedimentary rocks are not the focus of the present study and were therefore not described.

\subsubsection{Structures in Sassenfjorden-Tempelfjorden}

Seismic data in Sassenfjorden-Tempelfjorden (Fig. 1ab) show that basement rocks and overlying, uppermost Devonian-Permian sedimentary rocks of the Billefjorden and Gipsdalen groups are folded into two open, upright, NW-SE- to WNW-ESE-trending fold structures that coincide with similarly trending, several kilometer-wide, elongated ridges representing an uplifted portion of the seafloor in Sassenfjorden and Billefjorden (Koehl, 2020; Koehl et al., 2020), and with steeply NNE-dipping, basement-seated faults mostly confined to basement (-Devonian?) rocks and uppermost Devonian-Mississippian coal-rich deposits of the Billefjorden Group, or that die out upwards in the lower part of the Gipsdalen Group (Fig. 5a). Based on the minor reverse, top-SSW offset of thickened uppermost DevonianMississippian sedimentary strata, it is probable that the two gentle fold structures formed in the early Cenozoic as faultpropagation folds due to upward propagation and reverse re- activation or overprinting of NNE-dipping basement-seated faults.

Seismic data in Sassenfjorden and Tempelfjorden also show that high-amplitude seismic reflections characterizing uppermost Devonian-Mississippian sedimentary rocks significantly thicken (by approximately twice as much) towards the south-southwest, near the intersection of the east-dipping Billefjorden Fault Zone with NNE-dipping basement-seated faults, potentially suggesting that uppermost DevonianMississippian rocks represent early syn-rift sedimentary deposits (Prosser, 1993) and are part of the initiation stage (Gawthorpe and Leeder, 2000) of the Billefjorden Trough (Fig. 5a-b). There, high-amplitude seismic reflections representing coal-rich uppermost Devonian-Mississippian strata display laterally disrupted, (SSW-)tilted, Z-shaped geometries (Fig. 5b and e) that contrast with continuous, subparallel, subhorizontal geometries of the reflections in the northeast (Fig. 5a and c-e). Since similar Z-shaped geometries interpreted as duplex structures comprised of bedding-parallel décollements (floor and roof thrusts) connected by beddingoblique link thrusts were encountered in locally thickened, coal-rich, uppermost Devonian-Mississippian sedimentary deposits in Pyramiden (Fig. 4b), it is conceivable that, in Sassenfjorden-Tempelfjorden too, significant rheological contrasts between uppermost Devonian-Mississippian coalcoaly shale and sandstone of the Billefjorden Group localized the formation of duplex-related décollements and thrust faults during early Cenozoic deformation.

Locally, moderate- to low-amplitude, subparallel seismic reflections of the Hultberget, Ebbadalen, Minkinfjellet, and Wordiekammen formations are disrupted by and slightly bending along moderate- to shallow-dipping, bedding-oblique reflections, which are interpreted as minor early Cenozoic thrust faults (Fig. 5a, c, d, and f). These minor thrusts appear to flatten downwards and die out within high-amplitude seismic reflections of the Billefjorden Group, thus supporting the presence of bedding-parallel décollements in uppermost Devonian-Mississippian sedimentary rocks (Fig. 5c).

Seismic reflections within the overlying Gipshuken Formation dip gently to moderately and display continuous to partly chaotic facies (Fig. 5f). These are disrupted by possible gently NE- to east- and SW- to west-dipping thrusts that seem to flatten downwards into the Top Wordiekammen Formation reflection, forming part of possible imbricate thrust systems (Fig. 5a, c, d, and f) resembling thrusts within coals and coaly shales of the Billefjorden Group (Fig. 4b). This interpretation is supported by onshore Eurekan thrust geometries on the northern shore of Sassenfjorden (Fig. S5). This suggests the presence of a décollement level (or levels) within the Wordiekammen Formation and/or at the boundary between the Wordiekammen and Gipshuken formations. Internal seismic packages within the Gipshuken Formation display significant thickness variations, pinching out laterally and, in places, becoming as thick as the whole Gip- 
shuken Formation (Fig. 5a, c, d, and f). These thickness variations are tentatively related to tectonic thickening due to early Cenozoic thrusting and, potentially, to the presence of partially mobile evaporite within the Gipshuken Formation (Dallmann et al., 1999).

\subsubsection{Structures in Reindalspasset}

Seismic data in Reindalspasset show a N-S-trending open fold structure (Fig. 5g). In Lower-Middle Devonian rocks, the lowermost part of the fold shows semi-continuous to chaotic, moderate- to low-amplitude, locally undulating seismic reflections that display intensive disruption and sigmoidshaped geometries (Fig. 5g). Moderate- to low-amplitude reflections within sigmoid-shaped seismic packages display Sand Z-shaped geometries that are disrupted respectively by moderately west- and east-dipping reflections that appear to be responsible for the thickening of internal units and that flatten and die out upwards prior to or at the boundary with overlying uppermost Devonian-Mississippian rocks (Fig. 5g). These sigmoid-shaped seismic packages are interpreted as thickened sheets crosscut by early Cenozoic thrust faults that, in places, form duplex structures comprised of floor and roof thrusts connected by link thrusts. Associated undulating reflection geometries are thought to represent folding. Based on the sub-continuous, low- to moderateamplitude seismic facies and on the presence of folds and bedding-subparallel thrusts, it is probable that (at least the upper part of) this seismic unit is composed of shale-rich, Lower-Middle Devonian sedimentary strata of the Wood Bay and/or Grey Hoek and/or Wijde formations.

The core of the fold is partly composed of gently westdipping to flat-lying, high-amplitude seismic reflections representing coal-rich sedimentary strata of the Billefjorden Group, which were penetrated by exploration well 7816/121 at a depth of $2261 \mathrm{~m}$ (Eide et al., 1991), i.e., $0.96 \mathrm{~s}$ (TWT; Fig. $5 \mathrm{~g}$ ). In the east, sedimentary strata of the Billefjorden Group can be traced as continuous, gently west-dipping, subparallel reflections that thicken westwards against the eastern limb of the fold and that are locally folded and disrupted by a few gently west-dipping, bedding-subparallel reflections that accommodate local thickening of the Billefjorden Group and, hence, may represent minor early Cenozoic thrust faults (Fig. 5g). High-amplitude reflections of the Billefjorden Group are thickest within the fold hinge, where they show undulating geometries and are intensively disrupted. These disruptions may be the result of early Cenozoic thrusting along low-angle, bedding-subparallel faults, which are probably responsible for the thickening of uppermost Devonian-Mississippian strata within the fold hinge and are possibly forming part of an antiformal stack or ramp anticline (Fig. 5g). The largest of these potential early Cenozoic thrusts localized along the boundary between uppermost Devonian-Mississippian and Pennsylvanian sedimentary strata, i.e., parallel to the eastern limb of the fold, and splays upwards into four faults. This fault and associated splays quickly die out upwards within the fold hinge in the upper part of the uppermost Devonian-Mississippian and in the lower part of the Pennsylvanian sedimentary succession, offset sediments of the Billefjorden and Gipsdalen groups in a reverse manner (possible repeated portion of the Billefjorden Group), and flatten into the base of the Billefjorden Group or uppermost part of the Lower-Middle Devonian succession (Fig. 5g). The lowermost splay of this thrust was most likely penetrated by exploration well 7816/12-1 and consists of phyllitic coal and sheared coaly shales of the Billefjorden Group (Eide et al., 1991; Fig. 5g). Beddingparallel thrusts in uppermost Devonian-Mississippian strata are further supported by the presence of an analogous, sub-horizontal, bedding-parallel fault within the overlying Middle-Upper Triassic sedimentary rocks of the Barentsøya Formation, which was also penetrated by well 7816/12-1 and represents a possible early Cenozoic décollement (Eide et al., 1991; see uppermost sub-horizontal fault in Fig. 5g).

Continuous to semi-continuous, parallel, dominantly moderate- to high-amplitude seismic reflections representing Pennsylvanian-lower Permian sedimentary strata of the Hultberget, Ebbadalen, Minkinfjellet, and Wordiekammen formations thicken eastwards and westwards away from the fold hinge, i.e., opposite to sedimentary rocks of the Billefjorden Group, and appear to be affected by much fewer disruptions and, therefore, to be only mildly deformed (Fig. $5 \mathrm{~g}$ ). Pennsylvanian-lower Permian strata are thickest along the eastern fold limb where they are crosscut by three splays of the early Cenozoic thrust localized along the boundary between the Billefjorden and Gipsdalen groups and by a steeply east-dipping brittle fault. This steeply east-dipping fault shows a planar geometry in cross section; thickening of the Hultberget, Ebbadalen, Minkinfjellet, and Wordiekammen formations in the hanging wall; and minor normal offsets of seismic reflections within these stratigraphic units, and it dies out within the lower part of the Wordiekammen Formation upwards and the upper part of the Lower-Middle Devonian succession downwards. Based on cross-section geometries, offset kinematics, and thickening of stratigraphic units, this steeply dipping normal fault is interpreted as a Carboniferous normal fault possibly representing the southwards continuation of the Billefjorden Fault Zone.

\section{Discussion}

\subsection{Implications of contractional duplexes and décollements in Devonian-Mississippian sedimentary rocks for Ellesmerian and Eurekan deformation}

Uppermost Devonian-Mississippian sedimentary rocks of the Billefjorden Group in Pyramiden (Fig. 4b) and Sassenfjorden-Tempelfjorden (Fig. 5a, b, d, and e) are ar- 
ranged in gently dipping duplexes comprised of interbedded coal-coaly shale and sandstone deposits with sigmoidal shear fabrics and (imbricate) link thrusts (McClay and Insley, 1986) connecting bedding-parallel décollements (roof and floor thrusts and detachments; McClay, 1992) localized along lithological boundaries. These structures and geometries are typical in coal deposits reworked by contractional deformation (Phillipson, 2003, 2005; Molinda, 2003; Elizalde et al., 2016). The interpretation of bedding-parallel décollements is supported by minor early Cenozoic thrusts crosscutting the Hultberget, Ebbadalen, Minkinfjellet, and Wordiekammen formations in Sassenfjorden-Tempelfjorden (Fig. 1ab) that flatten downwards and die out within sedimentary strata of the Billefjorden Group (Fig. 5c), and by the presence of analogous shallow-dipping, bedding-parallel décollements in uppermost Devonian-Mississippian coal and coalyshale sedimentary strata of the Billefjorden Group in Odellfjellet (Koehl and Muñoz-Barrera, 2018), in Robertsonbreen (between the uppermost Devonian-Mississippian Hørbyebreen Formation and Pennsylvanian-Permian Wordiekammen Formation; Dißmann and Grewing, 1997), in northeastern Bjørnøya (Koehl, 2021a), at Midterhuken, in St. Jonsfjorden (where the unconformity between uppermost DevonianMississippian and Pennsylvanian sedimentary rocks possibly acted as a décollement or subhorizontal thrust; Maher and Welbon, 1992; Gasser and Andresen, 2013; Fig. 1a), in Nordenskiöld Land (Braathen and Bergh, 1995), and, potentially, in Oscar II Land (Bergh and Andresen, 1990) and Wedel Jarlsberg Land-Torell Land (Dallmann and Maher, 1989; Fig. 1a). Imbrication within the duplexes in Pyramiden indicates top-west thrusting and most likely reflects Eurekan contraction-transpression since it is the only postMississippian episode of contraction-transpression recorded in Spitsbergen. Similar Eurekan duplex geometries with sigmoidal bedding surfaces and link thrusts were also observed in Triassic strata in Spitsbergen (Andresen et al., 1992; Haremo and Andresen, 1992; Andresen, 2009), thus further supporting an interpretation of early Cenozoic thrusting in Pyramiden.

In Reindalspasset, potential décollements and low-angle thrusts folded into a gentle upright anticline and possibly forming an antiformal thrust stack were identified on seismic data within Lower-Middle Devonian strata of the Wood Bay and/or Grey Hoek and/or Wijde Bay formations and uppermost Devonian-Mississippian rocks of the Billefjorden Group (Fig. 5g). In tectonically thickened and mildly folded uppermost Devonian-Mississippian rocks, low-angle brittle-ductile thrust faults are comprised of phyllitic (i.e., sheared) and brittle coals (penetrated by well 7816/12-1 at a depth of 2261-2280 m; Eide et al., 1991) that are similar to sheared uppermost Devonian-Mississippian coals in Pyramiden and are arranged into potential duplexes that are comparable to duplexes and thrust systems in uppermost DevonianMississippian sedimentary rocks in Pyramiden (Figs. 1 and 4b) and Sassenfjorden-Tempelfjorden (Figs. 1 and 5b, e).
The geometries of these duplexes, thrusts, and décollements on seismic data in Spitsbergen are similar to analogous structures on seismic data worldwide (e.g., Morley et al., 2017, their Fig. 8). Potential Lower-Middle Devonian rocks show sigmoid-shaped duplex structures, décollements, folding and thrusting comparable to deformation structures in analogous rocks in Andrée Land, e.g., Bråvallafjella Fold Zone (Piepjohn, 2000; Dallmann and Piepjohn, 2020), and in southern Spitsbergen (e.g., Røkensåta; Fig. 1a; Dallmann, 1992), thus potentially supporting the preservation of Devonian sedimentary rocks of the Andrée Land Group (and/or Mimerdalen Subgroup) east of the Billefjorden Fault Zone in Reindalspasset, pending that the observed normal fault does actually represent the southern continuation of the Billefjorden Fault Zone (Fig. 5g; see Sect. 5.3). The presence of décollements within Lower-Middle (-lowermost Upper?) Devonian rocks is further supported by the observation of similar structures between shale and sandstone units of the Wood Bay and Grey Hoek formations in Andrée Land (Roy, 2007, 2009).

Based on the significant differences in deformation styles, it is probable that the décollements and backward-dipping duplexes in sheared uppermost Devonian-Mississippian coals-coaly shales decoupled early Cenozoic Eurekan deformation between folded, shale-rich, Lower Devonian rocks and undeformed to poorly deformed uppermost DevonianPermian sedimentary strata in Pyramiden (Figs. 3 and 4b). Seismic data in Sassenfjorden-Tempelfjorden also show potential duplexes and décollements within uppermost Devonian-Mississippian coal-rich deposits (Fig. 5a, b, d, and e). In these fjords, steeply dipping, basement-seated brittle faults seems to have propagated upwards during early Cenozoic Eurekan deformation, resulting in fault-propagation folding and reverse offsets in uppermost Devonian-Permian sedimentary strata (Fig. 5a and c). These faults die out upwards within uppermost Devonian-Pennsylvanian sedimentary rocks, while minor early Cenozoic thrusts crosscutting Pennsylvanian-Permian sedimentary strata appear to flatten downwards and die out into high-amplitude seismic reflections interpreted as uppermost Devonian-Mississippian coals, thus also suggesting decoupling of Eurekan deformation by early Cenozoic décollements in uppermost Devonian-Mississippian coals of the Billefjorden Group.

In Reindalspasset, early Cenozoic duplexes and thrusts within potential Lower-Middle Devonian strata of the Wood Bay and/or Grey Hoek and/or Wijde Bay formations die out upwards and minor thrusts within Pennsylvanian-Permian rocks die out downwards near or at the boundary with coalrich sedimentary rocks of the Billefjorden Group (Fig. 5g), thus also supporting the presence of early Cenozoic décollements within uppermost Devonian-Mississippian coaly shales and coals and (partial) decoupling of Eurekan deformation. Thickened coal-rich deposits are long known to be able to decouple deformation both in contractional (Frodsham and Gayer, 1999, their Figs. 1b, 2, 7, and 9) and ex- 
tensional settings (Wilson and Wojtal, 1986, their Figs. 7 and 10). In Svalbard, recent field studies by Koehl and MuñozBarrera (2018) in the northern part of the Billefjorden Trough in Odellfjellet (Fig. 1b) showed that bedding-parallel duplexshaped décollements in uppermost Devonian-Mississippian coaly shales may have partly inhibited early Cenozoic Eurekan contraction-transpression in overlying Pennsylvanian strata, thus further supporting the presence of such décollements in Pyramiden (Fig. 4b), Sassenfjorden-Tempelfjorden (Fig. 5a-f), and Reindalspasset (Fig. 5g).

Uppermost Devonian-Mississippian coal-rich strata are locally thicker in Pyramiden, thus resulting in their exploitation by Russia until the early 1990s (Livshitz, 1966; Cutbill et al., 1976). They are also thicker in Sassenfjorden in the hanging wall of the east-dipping Billefjorden Fault Zone near the intersection with a NNE-dipping basement-seated fault (Figs. 1 and 5a-d), and within the hinge zone of the anticline adjacent to the possible southward continuation of the Billefjorden Fault Zone in Reindalspasset (Fig. 5g). Recent studies of sedimentary rocks of the Billefjorden Group in the Ottar Basin (Tonstad, 2018), the Finnmark Platform (Koehl et al., 2018) in the SW Barents Sea, and the northern part of the Billefjorden Trough (Koehl and Muñoz-Barrera, 2018) show that uppermost Devonian-Mississippian sedimentary strata were deposited into subsiding basins bounded by normal faults. In addition, high-amplitude seismic reflections in the Ottar Basin representing thickened, coal-rich, uppermost Devonian-Mississippian sedimentary strata analog to those observed in Sassenfjorden-Tempelfjorden are thickest on basin edges where fluvial systems dominated in the latest Devonian-Mississippian times (Tonstad, 2018). It is possible that, in Spitsbergen too, thick uppermost DevonianMississippian coal seams were restricted to the basin edges along boundary faults. This would explain the localization of contractional duplexes and décollements in areas such as Pyramiden, Sassenfjorden, Reindalspasset, and (potentially) Triungen during early Cenozoic deformation. These contractional duplexes partially decoupled deformation between Lower Devonian to lowermost Upper Devonian sedimentary rocks of the Andrée Land Group and Mimerdalen Subgroup and thick Pennsylvanian-Permian deposits of the Gipsdalen Group and locally shielded the latter from Eurekan deformation, while Pennsylvanian sedimentary rocks in basinal areas in the hanging wall of the Odellfjellet Fault were involved in Eurekan deformation, and Carboniferous normal faults were inverted, e.g., in Odellfjellet (Koehl and Muñoz-Barrera, 2018), Løvehovden-Hultberget (Dallmann, 1993; Maher and Braathen, 2011), Adolfbukta (Harland et al., 1988), Lykteneset (Koehl et al., 2020), Anservika (Ringset and Andresen, 1988), and Sassenfjorden (Fig. 5a-f).

Based on field and seismic data in central Spitsbergen (present study; Koehl and Muñoz-Barrera, 2018; Koehl et al., 2020) and on analog modeling (Bonini, 2001), it is possible that Lower Devonian to lowermost Upper Devonian sedimentary deposits of the Andrée Land Group and Mimerdalen
Subgroup were folded exclusively in early Cenozoic times since the differences in deformation style and intensity between Devonian and Carboniferous-Permian deposits can be explained simply by decoupling of Eurekan deformation by weak, uppermost Devonian-Mississippian, coal- and shale-rich sedimentary deposits of the Billefjorden Group (Figs. 4b, and 5a-e and g; Koehl and Muñoz-Barrera, 2018). Hence, a short-lived episode of Late Devonian (Ellesmerian) deformation is not required to explain differential deformation within Lower Devonian to Permian sedimentary successions in central Spitsbergen, thus potentially simplifying the late Paleozoic tectonic history of the area by reducing it to the Caledonian Orogeny and late-post-Caledonian extensional collapse-rifting. This is further supported by a field study in Robertsonbreen (central Spitsbergen; Fig. 1b), where Dißmann and Grewing (1997) noticed that sedimentary strata of the lowermost Upper Devonian Plantekløfta Formation and uppermost Devonian-Mississippian Hørbyebreen Formation are both similarly folded, i.e., suggesting that early Cenozoic deformation may be (at least partially) responsible for folding of Lower Devonian to lowermost Upper Devonian rocks of the Andrée Land Group and Mimerdalen Subgroup in central Spitsbergen.

Strain decoupling, décollements and contractional duplexes are common features in the West Spitsbergen Foldand-Thrust Belt and were described at various locations and within varied rock types and stratigraphic units. Notably, Ringset and Andresen (1988) and Harland et al. (1988) discussed the presence of subhorizontal, bedding-parallel décollements within Pennsylvanian evaporites of the Ebbadalen and Minkinfjellet formations in eastern Billefjorden, from which early Cenozoic Eurekan thrusts may have ramped upwards into trailing imbricate fans (Boyer and Elliott, 1982) due to lateral lithological variations within Pennsylvanian formations (Ringset and Andresen, 1988). In addition, in western Spitsbergen, Maher (1988), Saalmann and Thiedig (2000), and Bergh and Andresen (1990) described early Cenozoic décollements and gently hinterland-dipping duplexes in uppermost Pennsylvanian-Permian sedimentary deposits of the Wordiekammen, Gipshuken, and Kapp Starostin formations, which may represent analogs to duplex structures and associated bedding-parallel décollements and low-angle thrusts within uppermost Devonian-Mississippian coals and coaly shales in Pyramiden, SassenfjordenTempelfjorden, and Reindalspasset (Figs. 4b and 5). It is worth noting that a model of critical wedge taper for the West Spitsbergen Fold-and-Thrust Belt predicted an increasing influence of decoupling (as observed in Pyramiden, Sassenfjorden-Tempelfjorden, and Reindalspasset; Figs. 4b and 5) towards the foreland of the fold and thrust belt, i.e., near the study area in central Spitsbergen (Braathen et al., 1999). All these earlier models and observations are in agreement with the model of strain partitioning and decoupling along bedding-parallel décollements and thrusts proposed by the present study in Pyramiden. 


\subsection{Formation mechanism for duplexes and décollements in uppermost Devonian-Mississippian rocks in Pyramiden}

Backward-dipping duplexes in Pyramiden are juxtaposed against east-dipping (and locally overturned west-dipping) Devonian strata of the Andrée Land Group and Mimerdalen Subgroup (Figs. 2 and $3 \mathrm{a}$ and $\mathrm{b}$ ) adjacent to and showing similar attitude to major fold structures in Mimerdalen thus far ascribed to the Ellesmerian Orogeny (Vogt, 1938; Piepjohn, 2000; Bergh et al., 2011). It is possible that, during early Cenozoic folding, Lower Devonian to lowermost Upper Devonian rocks of the Andrée Land Group and Mimerdalen Subgroup in the west may have acted as a relatively rigid buttress, i.e., partly deforming but not as easily as overlying weak uppermost Devonian-Mississippian coals and coaly shales of the Billefjorden Group that localized the formation of duplexes and décollements, thus allowing these structures to ramp upwards to the west. This is supported by field studies (Fard et al., 2006) and analog modeling (Bahroudi and Koyi, 2003) in the Zagros Fold-and-Thrust Belt showing buttressing, backward-dipping duplexes and décollements in the hanging wall of deep-seated faults, and by analog modeling of décollements in weak sedimentary layers with limited lateral extent (Costa and Vendeville, 2002, their model 3). Notably, Costa and Vendeville's model shows that initially sub-horizontal sedimentary strata may have been tilted backwards (i.e., eastwards in Pyramiden) during contraction, and that décollement lithology (i.e., uppermost DevonianMississippian coal-coaly shale) may be incorporated and transported (top-west to top-WNW in Pyramiden; Fig. 4a) as part of the hanging wall sequence during thrusting. In Pyramiden, this is supported by drill data from Trust Arktikugol showing that coal seams of the Billefjorden Group at the mine continue eastwards and preserve a gentle-moderate dip to the east (Aakvik, 1981, his Fig. 8.2.5). This interpretation implies the presence of the Balliolbreen Fault in Pyramiden, which is discussed in Sect. 5.3.

Another possibility is that the Pyramiden outcrop represents a mildly inverted extensional fault block that was gently folded due to upward propagation of the Balliolbreen Fault (if present at all in Pyramiden; see Sect. 5.3) and Odellfjellet Fault (e.g., gentle tilt to the east-southeast of strata of the Minkinfjellet Formation in Pyramiden; Koehl et al., 2016). Fault-propagation folds (Schlische, 1995) were discussed along the Løvehovden Fault (Maher and Braathen, 2011) and Billefjorden Fault Zone (Braathen et al., 2011; Bælum and Braathen, 2012) in cental Spitsbergen. However, this model implies the existence of the Balliolbreen Fault in Pyramiden as a steeply east-dipping fault, which is not obvious (see Sect. 5.3), and, alone, does not explain the presence of bedding-parallel décollements and backwarddipping duplexes within uppermost Devonian-Mississippian coals and coaly shales of the Billefjorden Group in Pyramiden and Sassenfjorden-Tempelfjorden (Figs. $4 \mathrm{~b}$ and 5b, e).
Moreover, seismic data in Reindalspasset show that a steeply east-dipping normal fault potentially representing the southwards continuation of the Billefjorden Fault Zone (Odellfjellet Fault?) is located along the eastern flank of a broad, gentle anticline (Fig. $5 \mathrm{~g}$ ) and, hence, might be related to (or might have interacted with) the fold structure but is most likely not the cause of folding in this area.

Analog modeling of inversion in asymmetric half-graben basins shows features similar to those observed in Pyramiden, demonstrating a potential relationship between weak, early syn-rift sedimentary deposits and segments of basinbounding faults (Buiter and Pfiffner, 2003, their Fig. 6a). Notably, in the presence of weak, syn-rift sedimentary rocks in basin-edge fault blocks, newly formed shortcut shear zones or faults (McClay, 1989) may branch off preexisting inverted basin-bounding normal faults and ramp up into the weak, syn-rift sedimentary strata, potentially using décollement levels to accommodate contraction. Buiter and Pfiffner (2003) further argue that basement blocks experience much less contraction-related rotation along preexisting normal faults. Thus, a possible scenario for the early Cenozoic tectonic history of the Billefjorden Fault Zone in Pyramiden might involve the formation of a shortcut shear zone or fault along an inverted portion of the Billefjorden Fault Zone at depth, branching off and ramping upwards into weak, coaland coaly-shale-dominated syn-rift sedimentary rocks of the Billefjorden Group, forming bedding-parallel décollements (Phillipson, 2003, 2005; Molinda, 2003; Elizalde et al., 2016) and east-dipping, backward-dipping duplexes (Fig. 4b).

Alternatively, early Cenozoic reverse reactivation or overprinting of the potentially upward-flattening Balliolbreen Fault (if present at all in Pyramiden; see Sect. 5.3) might have triggered the development of a décollement within and of a fault-bend hanging wall anticline (e.g., the Kuqa Fold Belt in northwestern China; Wang et al., 2013; Izquierdo-Llavall et al., 2017) above uppermost Devonian-Mississippian coals, e.g., in Reindalspasset (Fig. 5g). In this scenario, backwarddipping duplexes and décollements in uppermost DevonianMississippian coals-coaly shales may have acted as a roof décollement decoupling uppermost Devonian-Permian strata from (Lower-lowermost Upper) Devonian rocks, passively thrusting the former over the latter (Bonini, 2001). Through this process, the length of the roof sequence (uppermost Devonian-Permian sedimentary strata) remains essentially the same, whereas the length of the floor sequence (Lower Devonian to lowermost Upper Devonian rocks of the Andrée Land Group and Mimerdalen Subgroup) decreases through intense folding (Bonini, 2001). This may (partially) explain the significant differences of deformation between folded Lower Devonian to lowermost Upper Devonian of the Andrée Land Group and Mimerdalen Subgroup (Vogt, 1938; Harland et al., 1974; Piepjohn et al., 1997; Michaelsen et al., 1997; Michaelsen, 1998; Piepjohn, 2000), strongly sheared uppermost Devonian-Mississippian strata of the Billefjorden Group (Fig. 4b), and poorly deformed to gently 
tilted uppermost Devonian-Permian strata of the Billefjorden and Gipsdalen groups in central Spitsbergen (e.g., Braathen et al., 2011) without a short-lived episode of Ellesmerian contraction in the Late Devonian. The lack of uppermost Devonian-Mississippian coals and coaly shales of the Billefjorden Group directly on top of folded Lower (-lowermost Upper?) Devonian sedimentary rocks above the mine entrance in Pyramiden may suggest that uppermost DevonianMississippian coals-coaly shales were too thin or too localized (syn-rift?) to allow décollements to ramp all the way up to the mine entrance or that early Cenozoic Eurekan contraction-transpression was too mild to form a complete ramp-anticline (assuming that the Balliolbreen Fault is present in Pyramiden) with roof décollement over Lower Devonian sedimentary rocks (e.g., Faisal and Dixon, 2015).

Another plausible interpretation might be that of (a) westdirected imbricate fan(s) in Pennsylvanian evaporitic deposits and/or uppermost Devonian-Mississippian coals and coaly shales at depth in the Billefjorden Trough with eastdipping imbricate thrusts ramping upwards into coals and coaly shales of the Billefjorden Group in the footwall of the Odellfjellet Fault, in Pyramiden. This interpretation is supported by field studies of Ringset and Andresen (1988), who discussed imbricate (thrust) fans and associated basal décollement developed along lithological boundaries within the Ebbadalen Formation in Anservika-Gipshuken (see Fig. 1b for location); by Harland et al. (1988), who described sheared evaporites within the Ebbadalen and Gipshuken formations in eastern Billefjorden; and by recent field studies showing the presence of a potentially gently east-dipping, beddingparallel thrust-décollement within the Billefjorden Group and Hultberget Formation in Anservika (Tormod Henningsen et al., personal communication, 2019), and within the Hultberget Formation in Lykteneset (Koehl et al., 2020).

Based on field data, backward-dipping duplexes and bedding-parallel décollements in uppermost DevonianMississippian coals and coaly shales of the Billefjorden Group in Pyramiden are believed to have formed through a combination of at least two or more mechanisms, including Devonian rocks of the Andrée Land Group and Mimerdalen Subgroup acting as a relatively rigid buttress to the west (e.g., Fig. 5g), fault-propagation folding of a preexisting fault (or faults) like the Balliolbreen Fault and/or Odellfjellet Fault (although not very likely), shortcut faulting propagating upwards and westwards from the Billefjorden Fault Zone (e.g., Buiter and Pfiffner, 2003), ramp or fault-bend hanging wall anticline with roof décollement (e.g., Faisal and Dixon, 2015), and imbricate fan with basal décollement in the Billefjorden Trough (e.g., Ringset and Andresen, 1988; Tormod Henningsen et al., personal communication, 2019).

\subsection{Geometry and kinematics of the Balliolbreen Fault and implications for Ellesmerian and Eurekan deformation events, and Carboniferous normal faulting}

Structural field analysis in the gully below the entrance of the Russian coal mine in Pyramiden has shown the presence of a sub-vertical, steeply east-dipping brittle fault tentatively interpreted as the Balliolbreen Fault and comprised of cataclastic fault rock that, half-way to the mine, crosscuts steeply east-dipping, quartzitic (Lower-lowermost Upper?) Devonian sedimentary rocks involved in a fold structure with bedding locally overturned to the east (Figs. 3, 4a, S3). Thin section analysis on both sides of this fault (Fig. S1) shows cataclased (Lower-lowermost Upper?) Devonian quartzitic sandstone both in the fault footwall and hanging wall, suggesting that there are no basement rocks at this locality, which is supported by geological maps of Harland et al. (1974), Aakvik (1981), and Lamar et al. (1986) and geological maps and logs of Trust Arktikugol (1988; Alexander Sirotkin, personal communication, 2019). In addition, the steeply east-dipping fault does not seem to extend upwards into overlying uppermost Devonian-Mississippian clastic deposits above phyllitic coal-rich sedimentary strata. It is possible that the décollements within uppermost DevonianMississippian coals-coaly shales represent the upward lowangle continuation of the steeply east-dipping fault, but the structural location of the décollements (almost directly over the fault) would require an abrupt change of geometry of the fault from subvertical to low-angle (ca. 30 ; Fig. 4b) within a narrow zone, which is unlikely. In addition, fault surfaces and lithological transitions switch from dominant $\mathrm{N}-$ $\mathrm{S}$ to NNW-SSE strikes and trends in uppermost DevonianMississippian coals-coaly shales below the coal-mine entrance (Figs. 3 and 4a, and stereonet 3 in Fig. 3) to dominantly WNW-ESE in Lower (-lowermost Upper?) Devonian rocks and uppermost Devonian-Mississippian sandstone above the mine entrance (Figs. 3 and 4a, and stereonet 2 in Fig. 3), i.e., parallel to most outcrops sections of uppermost Devonian-Mississippian strata in this part of the study area.

Above the coal mine in Pyramiden, the contact between Lower (-lowermost Upper?) Devonian sedimentary strata and uppermost Devonian-Mississippian sedimentary rocks is not clearly exposed (partly loose blocks) and its nature is relatively speculative. It may be (1) a (folded?) stratigraphic unconformity and/or (2) a bedding-parallel décollement. Based on the internal geometry of bedding surfaces and deformation state of uppermost Devonian-Mississippian sedimentary strata of the Billefjorden Group, which are arranged into contractional, west-verging duplexes separated by low-angle, bedding-parallel décollements (Fig. 4b), it is possible that the stratigraphic contact hosts a décollement, e.g., the potential prolongation of one of the décollements within coal- and coaly-shale-rich deposits of the Billefjor- 
den Group (Figs. 3 and 4b). However, uppermost DevonianMississippian deposits above the coal mine appear to consist only of clastic deposits and, hence, lack weak coals-coaly shales into which décollements preferentially localize. Thus, the contact between Lower (-lowermost Upper?) Devonian and uppermost Devonian-Mississippian sedimentary rocks above the mine in Pyramiden most likely corresponds to a (folded?) unconformity.

Even if the décollements within uppermost DevonianMississippian coals and shales (Fig. 4b) were to represent the upwards continuation of the steeply east-dipping fault (Fig. 3), these most likely do not extend into Lower (-lowermost Upper?) Devonian and uppermost DevonianMississippian sandstone units above the mine entrance. Based on the similarity between the strike and dip of the steeply east-dipping fault and the trend and dip of (locally overturned) Lower Devonian bedding surfaces in Pyramiden (Figs. 3 and 4a), it is possible that the steeply east-dipping fault formed as a minor, bedding-parallel (fold-limb parallel) fault related to post-Caledonian gravitational collapse processes and low-angle detachments (e.g., the Woodfjorden detachment in Andrée Land; Roy, 2007, 2009; Fig. 1a) in Lower Devonian to lowermost Upper Devonian sedimentary rocks of the Andrée Land Group and Mimerdalen Subgroup in northern Spitsbergen (e.g., Chorowicz, 1992), or formed as a minor, bedding-parallel Eurekan accommodation thrust (e.g., Cosgrove, 2015) in the early Cenozoic. Since no major fault was identified in Pyramiden it is probable that the Balliolbreen Fault does not crop out or is not present there. This is supported by microstructures along the steeply eastdipping fault in Pyramiden (Fig. 3), e.g., mild undulose extinction and limited recrystallization and low amounts of displacement along distributed brittle cracks in fault rock (Fig. S1), which indicate mild deformation associated with low-grade pressure-temperature conditions $\left(<280^{\circ} \mathrm{C}\right.$; Stipp et al., 2002).

In Reindalspasset, the planar, east-dipping normal fault that offsets Pennsylvanian-lower Permian sedimentary rocks may represent the potential continuation of the basinbounding Odellfjellet Fault ("BFZ?" in Fig. 5g), and the Eurekan thrust (and associated splays) localized along the boundary between uppermost Devonian-Mississippian and Pennsylvanian sedimentary successions (Fig. $5 \mathrm{~g}$ ) the continuation of the (inverted?) Balliolbreen Fault. Fault relationships in cross section in Reindalspasset are comparable to what is proposed for the Balliolbreen and Odellfjellet faults in Pyramiden, e.g., possible merging at depth and hundreds of meter- to kilometer-scale lateral spacing between the faults (see previous section), assuming that the Balliolbreen Fault is present in Pyramiden. The preservation of Lower Devonian to lowermost Upper Devonian sedimentary rocks of the Andrée Land Group and/or Mimerdalen Subgroup east of the Billefjorden Fault Zone in Reindalspasset suggests that this fault did not accommodate top-west reverse movement in Late Devonian times as proposed by previous works in Dickson Land (Vogt, 1938; Friend, 1961; Piepjohn, 2000; Dallmann and Piepjohn, 2020). Had such movements occurred, Devonian sedimentary rocks of the Andrée Land Group and/or Mimerdalen Subgroup in the upthrust block east of the Billefjorden Fault Zone would have been exposed and subjected to continental erosion. This is clearly not the case in Reindalspasset where potential Lower Devonian to lowermost Upper Devonian sedimentary rock units appear to thicken eastwards. The presence of Devonian sedimentary rock east of the Billefjorden Fault Zone in Reindalspasset is also supported by the interpretation of well bore data in the Raddedalen-1 well in Edgeøya (Harland and Kelly, 1997).

The Balliolbreen Fault displays significant along-strike variations in geometry and kinematics. In the north, in Odellfjellet and Sentinelfjellet (Fig. 1b), the Balliolbreen Fault dips ca. $60-65^{\circ}$ to the east and juxtaposes Precambrian basement rocks unconformably overlain by uppermost Devonian-Mississippian strata of the Billefjorden Group in the hanging wall against Lower Devonian strata of the Wood Bay Formation supposedly unconformably overlain by uppermost Devonian-Mississippian rocks of the Billefjorden Group (Harland et al., 1974; Lamar et al., 1986; Lamar and Douglass, 1995). In both Odellfjellet and Sentinelfjellet, it is unclear whether the Balliolbreen Fault offsets uppermost Devonian-Mississippian strata, or if the fault is unconformably overlain by uppermost Devonian-Mississippian rocks (Lamar et al., 1982, 1986; Lamar and Douglass, 1995). Although Harland et al. (1974) argue that the Triungen Member of the Hørbyebreen Formation is unfaulted in Sentinelfjellet (thus potentially supporting Late Devonian top-west thrusting along the Balliolbreen Fault and no further reactivation), stratigraphic contacts in this area are covered by scree and poorly to unexposed (like in Triungen in Fig. 4c-e) and inaccessible because they are located on very steep slopescliffs (see https://toposvalbard.npolar.no). The presence of newly evidenced décollements in the lower part of the Billefjorden Group in Pyramiden, Sassenfjorden-Tempelfjorden, and Reindalspasset (Figs. 4b and 5) suggests that the nature of the contact of the Billefjorden Group with underlying Devonian rock units must be interpreted with care, especially where covered by scree. If sedimentary strata of the Billefjorden Group are actually truncated by the Balliolbreen Fault in Sentinelfjellet (e.g., McCann, 1993, his Figs. 5.9 and 5.10), then early Cenozoic thrusting may, in conjunction with Carboniferous normal faulting, explain the observed juxtaposition of Precambrian basement and Lower Devonian sedimentary rocks (Fig. 6). In this scenario, basement rocks constituting the Caledonian Atomfjella Antiform were located close to the surface at the end of the Caledonian Orogeny, thus leaving no (or limited) accommodation space east of the Billefjorden Fault Zone in Ny-Friesland (Fig. 1a) during Devonian sedimentation sourced from the collapsing orogen and exhuming core complexes in the west and east (e.g., Bockfjorden Anticline; Braathen et al., 2018; Fig. 6a). In the Carboniferous, normal faulting and footwall rotation along 
the Odellfjellet Fault possibly exhumed or kept a small portion of basement rocks relatively close to the surface in the footwall of the fault (Fig. $6 b-c)$. Later on, subsequent early Cenozoic deformation may have thrust part of the exposed basement rocks in the footwall as a kilometer-scale lens along a possibly inverted Carboniferous normal fault, the Balliolbreen Fault (Fig. 6d) potentially leading to extensive deformation of Lower Devonian to lowermost Upper Devonian rocks in Dickson Land, which acted as a buttress absorbing most of Eurekan deformation together with sheared uppermost Devonian-Mississippian coals and shales of the Billefjorden Group (note that deformation within Lower Devonian to lowermost Upper Devonian rocks is not detailed in Fig. 6d). In this model, Carboniferous normal and early Cenozoic reverse offsets along the Balliolbreen Fault have similar magnitude, as shown in Mumien (juxtaposition of the Ebbadalen Formation and Billefjorden Group against the Wordiekammen Formation and the Billefjorden Group with no apparent offset at the top Billefjorden Group level; Dallmann et al., 2004; Dallmann, 2015; Fig. 1b), and in Sentinelfjellet and Odellfjellet (the top of Billefjorden Group offset by 0-40 m; Harland et al., 1974; Lamar et al., 1986; Fig. 6e). Thus, it is possible that the above mentioned localities reflect different structural levels of the same fault system (Fig. 6e). Eurekan inversion of Carboniferous normal faults in central Spitsbergen is also supported by reverse offset and thrustrelated folding along the Overgangshytta fault in Odellfjellet (Koehl and Muñoz-Barrera, 2018), and by minor reverse offset of thickened, uppermost Devonian-Mississippian and Pennsylvanian sedimentary deposits in the hanging wall of the east-dipping Billefjorden Fault Zone, near the intersection with a steeply NNE-dipping basement-seated fault in Sassenfjorden (Fig. 5b).

The high degree of uncertainty in the relationship (truncated or truncating) between the Balliolbreen Fault and uppermost Devonian-Mississippian sedimentary strata of the Billefjorden Group (especially in Odellfjellet and Sentinelfjellet; Harland et al., 1974; Lamar et al., 1986; Lamar and Douglass, 1995) and the uncertainty regarding the nature of the contact (unconformity or bedding-parallel décollementsthrusts) between Lower Devonian and uppermost DevonianMississippian sedimentary strata shed by the presence of bedding-parallel Eurekan décollements and thrusts in Pyramiden (Fig. 4b), Sassenfjorden-Tempelfjorden (Fig. 5b, c and e), and Reindalspasset (Fig. 5g) call for caution and further (re-)examination of outcrops of uppermost DevonianMississippian rocks along the Balliolbreen Fault in central Spitsbergen.

Strong inconsistencies are observed along the Billefjorden Fault Zone, and these include (1) significant along-strike differences in cross-section geometry, (2) strong contrasts in offset stratigraphic units, and (3) inconsistencies in the inferred timing and kinematics. Considering along-strike variations in cross-section geometry, the Billefjorden Fault Zone is subvertical in Pyramiden (if present at all; Figs. 3 and (a) Devonian normal faulting

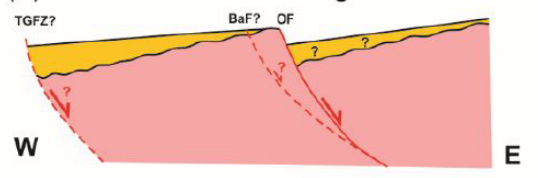

(b) Latest Devonian-Mississippian normal faulting

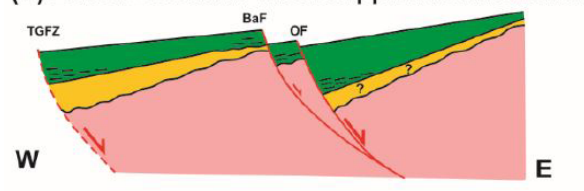

(c) Latest Mississippian-Pennsylvanian normal faulting

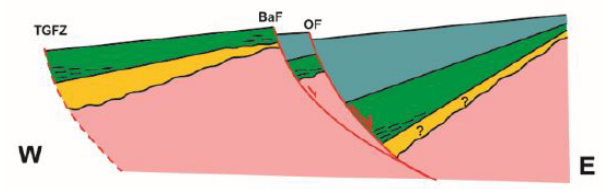

(d) Cenozoic thrusting

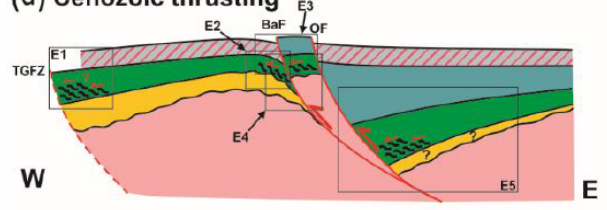

(e) Analog localities

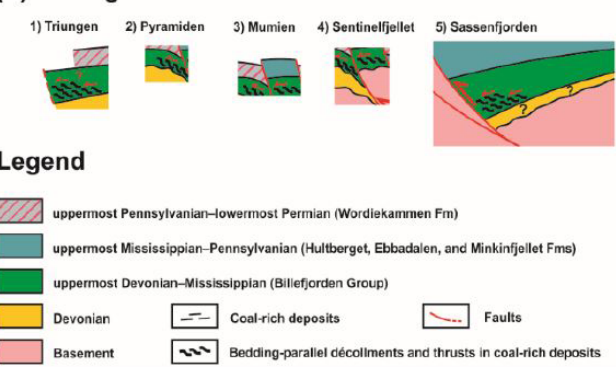

Figure 6. Schematic cross sections showing the possible evolution of the Billejorden Fault Zone and its relationship with deformation within the Billefjorden Group in Devonian-early Cenozoic times. (a) Relatively high pre-Devonian basement rocks in the east and a collapse basin in the west with erosion-related exhumation of basement rocks in the footwall of the Odellfjellet Fault. (b) Widespread latest Devonian-Mississippian normal faulting and localization of thick coal deposits on basin edges. (c) Latest Mississippian-Pennsylvanian normal faulting localized along the Billefjorden Fault Zone (Balliolbreen and Odellfjellet faults). (d) Inversion of Devonian-Carboniferous normal faults and basins during early Cenozoic Eurekan deformation, including top-west thrusting of Proterozoic basement onto Lower Devonian to lowermost Upper Devonian rocks of the Andrée Land Group and Mimerdalen Subgroup along the Balliolbreen Fault, the formation of bedding-parallel décollements and thrusts in uppermost Devonian-Mississippian coal-rich deposits, and intense internal deformation of Lower Devonian to lowermost Upper Devonian sedimentary rocks (not detailed here) that acted as a buttress. (e) Parts of the cross section in (d) that fit field observations (from the present contribution and by previous workers) in key localities discussed in the text (Fig. 1a-b). The location of the schematics in (e) is shown as black frames in (d). Abbreviations - BaF: Balliolbreen Fault; OF: Odellfjellet Fault; TGFZ: Triungen-Grønhorgdalen Fault Zone. 
4b) but dips more gently in Reindalspasset (Eurekan thrust localized along the Billefjorden-Gipsdalen group boundary; Fig. 5g).

Regarding offset stratigraphy, the Billefjorden Fault Zone juxtaposes Pennsylvanian rocks of the Ebbadalen Formation overlain by carbonates of the Wordiekammen Formation in the hanging wall against Lower Devonian rocks of the Wood Bay Formation unconformably overlain by strata of the Wordiekammen Formation in the footwall in Yggdrasilkampen (Dallmann et al., 2004; Fig. 1b). By contrast, the fault juxtaposes strata of the Pennsylvanian Ebbadalen Formation against rocks of the uppermost Pennsylvanianlower Permian Wordiekammen Formation in Mumien (Dallmann et al., 2004; Dallmann, 2015). Other configurations show the fault bounding Lower Devonian rocks overlain by the uppermost Devonian-Mississippian Billefjorden Group in the hanging wall from Lower Devonian rocks in the footwall in Pyramiden (if present at all; Figs. 3 and 4a), and Precambrian basement rocks in the hanging against Lower Devonian rocks the footwall in Odellfjellet and Sentinelfjellet (Harland et al., 1974; Lamar et al., 1986).

With respect to the inferred timing of faulting and related kinematics, the Billefjorden Fault Zone is thought to have accommodated Carboniferous normal faulting in Yggdrasilkampen (Dallmann et al., 2004), early Cenozoic reverse movement in Pyramiden (if present at all; Fig. 4b) and possibly in Reindalspasset (if present at all; Fig. 5g) and Flowerdalen (Harland et al., 1974; Haremo et al., 1990; Haremo and Andresen, 1992), Carboniferous normal and early Cenozoic reverse faulting in Mumien (Dallmann, 2015), and potential Late Devonian (e.g.,Harland et al., 1974; Piepjohn, 2000; Dallmann and Piepjohn, 2020) or early Cenozoic thrusting (this study; Koehl and Muñoz-Barrera, 2018) in Odellfjellet and Sentinelfjellet. All these inconsistencies suggest that the Balliolbreen Fault might consist of several discrete, disconnected (soft-linked and/or stepping?) or possibly offset fault segments crosscut by suborthogonal faults (McCann, 1993, his Fig. 5.11; Koehl, 2020).

For example, a basement-seated reverse fault in Sassenfjorden-Tempelfjorden accommodated top-SSW thrusting during Eurekan deformation (Fig. 5a-b) and seems to have limited the amount of Eurekan reactivation or overprinting (strain partitioning) along east-dipping segments of the Billefjorden Fault Zone in this area, which shows mainly down-east Carboniferous normal offset with a limited amount of early Cenozoic reworking along the main east-dipping fault (e.g., Fig. 5d), and may be responsible for restricting sediment deposition or preservation to the southwest of Sassenfjorden during Eurekan tectonism in the early Cenozoic, thus explaining sediment provenance from the northeast (e.g., Petersen et al., 2016). Another example where strain partitioning may have occurred along suborthogonal faults is Yggdrasilkampen, where the possible continuation of the Balliolbreen Fault juxtaposes Pennsylvanian (hanging wall) against Lower Devonian (footwall) sedimentary rocks, suggesting that Carboniferous normal faulting was followed by limited early Cenozoic reactivation or overprinting if any at all. The character of the Billefjorden Fault Zone in Sassenfjorden and Yggdrasilkampen contrasts sharply with areas farther north (e.g., in Sentinelfjellet and Odellfjellet; Harland et al., 1974; Lamar et al., 1986; Lamar and Douglass, 1995; Dallmann et al., 2004; Dallmann, 2015) and farther south (e.g., in Flowerdalen; Harland et al., 1974; Haremo et al., 1990; Haremo and Andresen, 1992; Fig. 1b) where the east-dipping Billefjorden Fault Zone displays clear evidence of top-west Eurekan movements. More of these (WNW-ESE-striking) suborthogonal faults are described and their impact on Eurekan strain partitioning is further discussed in Koehl et al. (2020).

\section{Conclusion}

Thickened uppermost Devonian-Mississippian sedimentary deposits of the Billefjorden Group in central Spitsbergen are arranged in duplexes comprised of phyllitic coal-coaly shale interbedded with sandstone showing sigmoidal shear fabrics separated by imbricate thrusts linking upper (roof thrust) and lower (floor thrust) décollements that are localized along lithological transitions.

Early Cenozoic bedding-parallel décollements and thrusts in tectonically thickened, coal-rich sedimentary rocks of the Billefjorden Group, in the Wordiekammen Formation, and in Lower Devonian to lowermost Upper Devonian sedimentary rocks partially decoupled Eurekan deformation, resulting in intense folding in Devonian sedimentary rocks of the Andrée Land Group and Mimerdalen Subgroup and uppermost Devonian-Mississippian coals of the Billefjorden Group, and mild to no deformation in Carboniferous-Permian strata in central Spitsbergen, thus suggesting that Late Devonian Ellesmerian contraction is not required to explain differential deformation within Lower Devonian to Permian sedimentary successions in central Spitsbergen.

Early Cenozoic backward-dipping duplexes and beddingparallel décollements in the Billefjorden Group in Pyramiden formed through shortcut faulting propagating upwards and westwards from the Odellfjellet Fault, and/or as roof décollements of a ramp or fault-bend hanging wall anticline, and/or as part of an imbricate fan with basal décollement in the Billefjorden Trough. Early Cenozoic contractional structures in uppermost Devonian-Mississippian coals-coaly shales also include fault-propagation folds over preexisting basement-seated faults in Sassenfjorden, and a possible antiformal thrust stack (or ramp anticline) in Reindalspasset.

Lower Devonian to lowermost Upper Devonian sedimentary rocks might be preserved east of the Billefjorden Fault Zone in Reindalspasset, thus suggesting that the Billefjorden Fault Zone did not act as a reverse fault in Late Devonian times. 
Thrusting of Proterozoic basement rocks over Lower Devonian sedimentary rocks along the Balliolbreen Fault and fold structures within strata of the Andrée Land Group and Mimerdalen Subgroup in central Spitsbergen may be explained by a combination of down-east Carboniferous normal faulting with associated footwall rotation and exhumation, and subsequent top-west early Cenozoic Eurekan thrusting along the Billefjorden Fault Zone.

The uncertain relationship of the Balliolbreen Fault with uppermost Devonian-Mississippian sedimentary strata and the poorly constrained nature of the contact (unconformity or bedding-parallel décollements-thrusts) between Devonian of the Andrée Land Group and Mimerdalen Subgroup and uppermost Devonian-Mississippian sedimentary strata, as well as significant along-strike variations in cross-section geometry, offset stratigraphy, and inferred timing and kinematics suggest that the Balliolbreen Fault consists of several discrete, unconnected (soft-linked and/or stepping) or most likely offset fault segments that were reactivated or overprinted to varying degrees during Eurekan deformation due to strain partitioning along suborthogonal Eurekan reverse faults.

Data availability. High-resolution versions of the figures and supplements of the paper, necessary to identify individual reflections and structures, can be found at DataverseNO (https://doi.org/10.18710/IIHGSH, Koehl, 2021b).

Supplement. The supplement related to this article is available online at: https://doi.org/10.5194/se-12-1025-2021-supplement.

Competing interests. The author declares that there is no conflict of interest.

Acknowledgements. The present study is part of the ARCEx (Research Centre for Arctic Petroleum Exploration), which is funded by the Research Council of Norway (grant number 228107) together with 10 academic and 8 industry partners; the SEAMSTRESS project, which is supported by a starting grant of the Troms $\varnothing$ Research Foundation and the Research Council of Norway (grant number 287865); and the CEED (Centre for Earth Evolution and Dynamics), which is funded by the Research Council of Norway (grant number 223272). The author would like to thank all the persons from these institutions that are involved in this project. Most grateful thanks are owed to John Marshall (University of Southampton), Christopher Berry (University of Cardiff), Gilda Lopes (University of Algarve), and Gunn Mangerud (University of Bergen) for their help with the palynology of Devonian-Mississippian rocks in Spitsbergen. Many thanks to Alexander Andreas for field collaborations; to Steffen Bergh, Winfried Dallmann, Holger Stunitz, and Mélanie Forien (University of Troms $\varnothing$ ); and to Karsten Piepjohn (BGR) and Jaroslaw Majka (Uppsala University) for fruitful discussions. Sebastian Sikora and the University Centre in Svalbard
(UNIS) are thanked for boat transportation to Pyramiden in summer 2016. The Norwegian Petroleum Directorate, Equinor, and Store Norske Spitsbergen Kulkompani are thanked for granting access to seismic and well data. Many thanks to Ivar Stokkeland from the Norwegian Polar Institute Library in Troms $\varnothing$, Norway, for his help with finding old, non-digitized publications about the geology of Svalbard (available at the Norwegian Polar Institute Library in Troms $\varnothing$, Norway; list of publications included in Sect. S6 in the Supplement). The PhD thesis of John G. Gjelberg (1984) was also digitized and, thanks to the University of Bergen and to John G. Gjelberg's family, is now available from the University of Bergen Library at http://bora.uib.no/handle/1956/20981 (last access: 6 May 2021).

Financial support. This research has been supported by the ARCEx and SEAMSTRESS (grant nos. 228107 and 287865) and by the CEED (grant no. 223272).

Review statement. This paper was edited by Mark Allen and reviewed by Thomas Phillips and one anonymous referee.

\section{References}

Aakvik, R.: Fasies analyse av Undre Karbonske kullførende sedimenter, Billefjorden, Spitsbergen, $\mathrm{PhD}$ Thesis, University of Bergen, Bergen, Norway, 219 pp., 1981.

Allen, K. C.: Lower and Middle Devonian spores of north and central Vestspitsbergen, Palaeontology, 8, 678-748, 1965.

Allen, K. C.: Further information on the Lower and Middle Devonian spores from Dickson Land, Spitsbergen, Norsk Polarinstitutt Årbok 1971, 7-15, 1973.

Andresen, A.: Geology of Svalbard - A Window into the Barents Sea Hydrocarbon Province, Svalex 2009 cruise report, Statoil, 2009.

Andresen, A., Haremo, P., Swensson, E., and Bergh, S. G.: Structural geology around the southern termination of the Lomfjorden Fault Complex, Agardhdalen, east Spitsbergen, Norsk Geol. Tidsskr., 72, 83-91, 1992.

Andresen, A., Bergh, S. G., and Haremo, P.: Basin inversion and thin-skinned deformation associated with the Tertiary transpressional west Spitsbergen Orogen, in: Proceedings of the International Conference on Arctic Margins, edited by: Thurston, D. K. and Fujita, K., Anchorage, Alaska, USA, September 1992, 161166, 1994.

Bahroudi, A. and Koyi, H. A.: Effect of spatial distribution of Hormuz salt on deformation style in the Zagros fold and thrust belt: an analogue modelling approach, J. Geol. Soc. Lond., 160, 719733, 2003.

Balashov, Yu. A., Larionov, A. N., Gannibal, L. F., Sirotkin, A. N., Tebenkov, A. M., Ryüngenen, G. I., and Ohta, Y.: An Early Proterozoic $\mathrm{U}-\mathrm{Pb}$ zircon age from an Eskolabreen Formation gneiss in southern Ny Friesland, Spitsbergen, Polar Res., 12, 147-152, 1993.

Bælum, K. and Braathen, A.: Alongstrike changes in fault array and rift basin geometry of the Carboniferous Billefjorden Trough, Svalbard, Norway, Tectonophys., 546-547, 38-55, 2012. 
Beauchamp, B., Alonso-Torres, D., Piepjohn, K., Thériault, P., and Grasby, S. E.: Early Carboniferous syn-rift sedimentation in the Sverdrup Basin (Yelverton Pass area, northern Ellesmere Island, Arctic Canada): A solution to the Okse Bay problem, in: CircumArctic Structural Events: Tectonic Evolution of the Arctic Margins and Trans-Arctic Links with Adjacent Orogens, edited by: Piepjohn, K., Strauss, J. V., Reinhardt, L., and McClelland, W. C., GSA Spec. Paper, 541, 255-284, 2018.

Bergh, S. G. and Andresen, A.: Structural development of the Tertiary fold-and-thrust belt in east Oscar II Land, Spitsbergen, Polar Res., 8, 217-236, 1990.

Bergh, S. G. and Grogan, P.: Tertiary structure of the SørkappHornsund Region, South Spitsbergen, and implications for the offshore southern continuation of the fold-thrust Belt, Norsk Geol. Tidsskr., 83, 43-60, 2003.

Bergh, S. G., Maher Jr., H. D., and Braathen, A.: Tertiary divergent thrust directions from partitioned transpression, Brøggerhalvøya, Spitsbergen, Norsk Geol. Tidsskr., 80, 63-82, 2000.

Bergh, S. G., Maher Jr., H. D., and Braathen, A.: Late Devonian transpressional tectonics in Spitsbergen, Svalbard, and implications for basement uplift of the Sørkapp-Hornsund High, J. Geol. Soc. Lond., 168, 441-456, 2011.

Berry, C. M. and Marshall, J. E. A.: Lycopsid forests in the early Late Devonian paleoequatorial zone of Svalbard, Geology, 43, 1043-1046, 2015.

Birkenmayer, K. and Turnau, E.: Lower Carboniferous age of the so-called Wijde Bay Series in Hornsund, Vestspitsbergen, Nor. Polarinst. Årb. 1961, 41-61, 1962.

Blinova, M., Faleide, J. I., Gabrielsen, R. H., and Mjelde, R.: Seafloor expression and shallow structure of a fold-and-thrust system, Isfjorden, west Spitsbergen, Polar Res., 31, 11209, https://doi.org/10.3402/polar.v31i0.11209, 2012.

Bonini, M.: Passive roof thrusting and forelandward fold propagation in scaled brittle-ductile physical models of thrust wedges, J. Geophys. Res., 106, 2291-2311, 2001.

Boyer, S. E. and Elliott, D.: Thrust Systems, AAPG Bulletin, 66, 1196-1230, 1982.

Braathen, A. and Bergh, S. G.: Kinematics of Tertiary deformation in the basement-involved fold-thrust complex, western Nordenskiøld Land, Svalbard: tectonic implications based on fault-slip data analysis, Tectonophys., 249, 1-29, 1995.

Braathen, A., Bergh, S. G., and Maher Jr., H. D.: Application of a critical wedge taper model to the Tertiary transpressional foldthrust belt on Spitsbergen, Svalbard, GSA Bull., 111, 1468-1485, 1999.

Braathen, A., Bælum, K., Maher Jr., H. D., and Buckley, S. J.: Growth of extensional faults and folds during deposition of an evaporite-dominated half-graben basin; the Carboniferous Billefjorden Trough, Svalbard, Norsk Geol. Tidsskr., 91, 137-160, 2011.

Braathen, A., Osmundsen, P. T., Maher Jr., H. D., and Ganerød, M.: The Keisarhjelmen detachment records Silurian-Devonian extensional collapse in Northern Svalbard, Terra Nova, 30, 3439, 2018.

Brinkmann, L.: Geologie des östlichen zentralen Dickson Landes und Palynologie der Mimerdalen Formation (Devon), Spitzbergen [Geology of eastern-central Dickson Land and palynology of the Mimerdalen Formation [Devonian], Spitsbergen], Master's Thesis, University of Münster, Münster, Germany, 94 pp., 1997.
Bugge, T., Mangerud, G., Elvebakk, G., Mørk, A., Nilsson, I., Fanavoll, S., and Vigran, J. O.: The Upper Palaeozoic succession on the Finnmark Platform, Barents Sea, Norsk Geol. Tidsskr., 75, 3-30, 1995.

Buiter, S. J. H. and Pfiffner, O. A.: Numerical models of the inversion of half-graben basins, Tectonics, 5, 1057, https://doi.org/10.1029/2002TC001417, 2003.

Chalmers, J. A. and Pulvertaft, T. C. R.: Development of the continental margins of the Labrador Sea: a review, in: Non-Volcanic Rifting of Continental Margins: A Comparison of Evidence from Land and Sea, edited by: Wilson, R. C. L., Taylor, R. B., and Froitzheim, N., Geol. Soc. Lond. Spec. Publ., 187, 77-105, 2001.

Chorowicz, J.: Gravity-induced detachment of Devonian basin sediments in northern Svalbard, Norsk Geol. Tidsskr., 72, 21-25, 1992.

Cosgrove, J. W.: The association of folds and fractures and the link between folding, fracturing and fluid flow during the evolution of a fold-thrust belt: a brief review, in: Industrial Structural Geology: Principles, Techniques and Integration, edited by: Richards, F. L., Richardson, N. J., Rippington, S. J., Wilson, R. W., and Bond, C. E., Geol. Soc. Lond. Spec. Publ., 421, 41-68, 2015.

Costa, E. and Vendeville, B. C.: Experimental insights on the geometry and kinematics of fold-and-thrust belts above weak, viscous evaporitic décollement, J. Struct. Geol., 24, 1729-1739, 2002.

Cutbill, J. L. and Challinor, A.: Revision of the Stratigraphical Scheme for the Carboniferous and Permian of Spitsbergen and Bjørnøya, Geol. Mag., 102, 418-439, 1965.

Cutbill, J. L., Henderson, W. G., and Wright, N. J. R.: The Billefjorden Group (Early Carboniferous) of central Spitsbergen, Norsk Polarinst. Skr., 164, 57-89, 1976.

Dallmann, W. K.: Multiphase tectonic evolution of the SørkappHornsund mobile zone (Devonian, Carboniferous, Tertiary), Svalbard, Norsk Geol. Tidsskr., 72, 49-66, 1992.

Dallmann, W. K.: Notes on the stratigraphy, extent and tectonic implications of the Minkinfjellet Basin, Middle Carboniferous of central Spitsbergen, Polar Res., 12, 153-160, 1993.

Dallmann, W. K.: Geoscience Atlas of Svalbard, Norsk Polarinstitutt, Troms $\varnothing$, Norway, Rapportserie nr. 148, 2015.

Dallmann, W. K. and Maher Jr., H. D.: The Supanberget area - basement imbrication and detached foreland thrusting in the Tertiary fold-and-thrust belt, Svalbard, Polar Res., 7, 95-107, 1989.

Dallmann, W. K. and Piepjohn, K.: The structure of the Old Red Sandstone and the Svalbardian Orogenic Event (Ellesmerian Orogeny) in Svalbard, Norg. Geol. Unders. B., 15, 106 pp., 2020.

Dallmann, W. K., Ohta, Y., and Andresen, A.: Tertiary Tectonics of Svalbard, Norsk Polarinstitutt Rapportserie, 46, 112 pp., 1988.

Dallmann, W. K., Andresen, A., Bergh, S. G., Maher Jr., H. D., and Ohta, Y.: Tertiary fold-and-thrust belt of Spitsbergen Svalbard, Norsk Polarinstitutt Meddelelser 128, 51 pp., 1993.

Dallmann, W. K., Dypvik, H., Gjelberg, J. G., Harland, W. B., Johannessen, E. P., Keilen, H. B., Larssen, G. B., Lønøy, A., Midbøe, P. S., Mørk, A., Nagy, J., Nilsson, I., Nøttvedt, A., Olaussen, S., Pcelina, T. M., Steel, R. J., and Worsley, D.: Lithostratigraphic Lexicon of Svalbard, edited by: Dallmann, W. K., Norwegian Polar Institute, Polar Environmental Centre, Troms $\varnothing$, Norway, 1999.

Dallmann, W. K., Piepjohn, K., and Blomeier, D.: Geological map of Billefjorden, Central Spitsbergen, Svalbard, with geological 
excursion guide, Scale $1: 50,000$, Temakart No. 36, Norsk Polarinstitutt, 2004.

Dallmann, W. K., Piepjohn, K., Blomeier, D., and Elvevold, S.: Geological map of Svalbard 1:100 000, sheet C8G, Billejorden, revised edition, Norsk Polarinstitutt Temakart, 43, 2009.

Davies, G. R. and Nassichuck, W. W.: An Early Carboniferous (Visean) Lacustrine Oil Shale in Canadian Arctic Archipelago, AAPG Bull., 72, 8-20, 1988.

Dißmann, B. and Grewing, A.: Post-svalbardische kompressive Strukturen im westlichen Dickson Land (Hugindalen), ZentralSpitzbergen, Münster. Forsch. Geol. Paläont., 82, 235-242, 1997.

Eide, J. R., Ree, R., and Rockman, P. O.: Final well report 7816/12-1 July 1991, Norsk Hydro A.S., Harstad, Norway, 1991.

Elizalde, C., Griffith, W. A., and Miller, T.: Thrust fault nucleation due to heterogeneous bedding plane slip: evidence from an Ohio coal mine, Eng. Geol., 206, 1-17, 2016.

Faisal, S. and Dixon, J. M.: Physical analog (centrifuge) model investigation of contrasting structural styles in the Salt Range and Potwar Plateau, northern Pakistan, J. Struct. Geol., 77, 277-292, 2015.

Fard, I. A., Braathen, A., Mokhtari, M., and Alavi, S. A.: Interaction of the Zagros Fold-Thrust Belt and the Arabian-type, deepseated folds in the Abadan Plain and the Dezful Embayment, SW Iran, Petrol. Geosci., 12, 347-362, 2006.

Fedorowski, J.: Coral thanatocoenoses and depositional environment in the upper Treskelodden beds of the Hornsund area, Spitsbergen, Palaeontologica Polonica, 43, 17-68, 1982.

Flood, B., Gee, D. G., Hjelle, A., Siggerud, T., and Winsnes, T. S.: The geology of Nordaustlandet, northern and central parts, Norsk Polarinst. Skr., 146, 145 pp., 1969.

Friend, P. F.: The Devonian stratigraphy of north and central Vestspitsbergen, P. Yorks. Geol. Soc., 33, 77-118, 1961.

Friend, P. F. and Moody-Stuart, M.: Sedimentation of the Wood Bay Formation (Devonian) of Spitsbergen: Regional analysis of a late orogenic basin, Norsk Polarinst. Skr., 157, 80 pp., 1972.

Friend, P. F., Heintz, N., and Moody-Stuart, M.: New unit terms for the Devonian of Spitsbergen and a new stratigraphical scheme for the Wood Bay Formation, Polarinst. Årbok, 1965, 59-64, 1966.

Friend, P. F., Harland, W. B., Rogers, D. A., Snape, I., and Thornley, R. S.: Late Silurian and Early Devonian stratigraphy and probable strike-slip tectonics in northwestern Spitsbergen, Geol. Mag., 134, 459-479, 1997.

Frodsham, K. and Gayer, R. A.: The impact of tectonic deformation upon coal seams in the South Wales coalfield, UK, Int. J. Coal Geol., 38, 297-332, 1999.

Gasser, D. and Andresen, A.: Caledonian terrane amalgamation of Svalbard: detrital zircon provenance of Mesoproterozoic to Carboniferous strata from Oscar II Land, western Spitsbergen, Geol. Mag., 150, 1103-1126, 2013.

Gawthorpe, R. L. and Leeder, M. R.: Tectono-sedimentary evolution of active extensional basins, Basin Res., 12, 195-218, 2000.

Gayer, R. A., Gee, D. G., Harland, W. B., Miller, J. A., Spall, H. R., Wallis, R. H., and Winsnes, T. S.: Radiometric age determinations on rocks from Spitsbergen, Norsk Polarinstitutt Skrifter, 137, 43 pp., 1966.

Gee, D. G. and Moody-Stuart, M.: The base of the Old Red Sandstone in central north Haakon VII Land, Vestspitsbergen, Polarinst. Årbok, 1964, 57-68, 1966.
Gee, D. G. and Page, L. M.: Caledonian terrane assembly on Svalbard: New evidence from ${ }^{40} \mathrm{Ar} /{ }^{39} \mathrm{Ar}$ dating in Ny Friesland, Am. J. Sci., 294, 1166-1186, 1994.

Gjelberg, J. G.: Upper Devonian (Famennian) - Middle Carboniferous succession of Bjørnøya, a study of ancient alluvial and coastal marine sedimentation, Norsk Polarinst. Skr., 174, 67 pp., 1981.

Gjelberg, J. G.: Early-Middle Carboniferous sedimentation on Svalbard. A study of ancient alluvial and coastal marine sedimentation in rift- and strike-slip basins, $\mathrm{PhD}$ Thesis, University of Bergen, Bergen, Norway, 306 pp., 1984.

Gjelberg, J. G. and Steel, R. J.: An outline of Lower-Middle Carboniferous sedimentation on Svalbard: Effects of tectonic, climatic and sea level changes in rift basin sequences, in: Geology of the North Atlantic Borderlands, edited by: Kerr, J. W. and Ferguson, A. J., Can. Soc. Petrol. Geol. Mem., 7, 543-561, 1981.

Hamilton, E., Harland, W. B., and Miller, J. A.: Isotopic Ages from Some Spitsbergen Rocks, Nature, 195, 1191-1192, 1962.

Haremo, P. and Andresen, A.: Tertiary décollements thrusting and inversion structures along Billefjorden and Lomfjorden Fault Zones, East Central Spitsbergen, in: Structural and Tectonic Modelling and its Apllication to Petroleum Geology, edited by: Larsen, R. M., Brekke, H., Larsen, B. T., and Talleraas, E., Norwegian Petroleum Society (NPF) Special Publications, 1, 481494, 1992.

Haremo, P., Andresen, A., Dypvik, H., Nagy, J., Elverøi, A., Eikeland, T. A., and Johansen, H.: Structural development along the Billefjorden Fault Zone in the area between Kjellströmdalen and Adventdalen/Sassendalen, central Spitsbergen, Polar Res., 8, 195-216, 1990.

Harland, W. B.: Contribution of Spitsbergen to understanding of tectonic evolution of North Atlantic region, AAPG Memoirs, 12, 817-851, 1969.

Harland, W. B. and Horsfield, W. T.: West Spitsbergen Orogen, in: Mesozoic-Cenozoic orogenic belts, edited by: Spencer, A. M., Geol. Soc. Lond. Spec. Publ., 4, 747-755, 1974.

Harland, W. B. and Kelly, S. R. A.: Eastern Svalbard Platform, in: Geology of Svalbard, edited by: Harland, W. B., Geol. Soc. London Mem., 17, 75-95, 1997.

Harland, W. B. and Wright, N. J. R.: Alternative hypothesis for the pre-Carboniferous evolution of Svalbard, Norsk Polarinst. Skr., 167, 89-117, 1979.

Harland, W. B., Cutbill, L. J., Friend, P. F., Gobbett, D. J., Holliday, D. W., Maton, P. I., Parker, J. R., and Wallis, R. H.: The Billefjorden Fault Zone, Spitsbergen - the long history of a major tectonic lineament, Norsk Polarinst. Skr., 161, 1-72, 1974.

Harland, W. B., Mann, A., and Townsend, C.: Deformation of anhydrite-gypsum rocks in central Spitsbergen, Geol. Mag., 125, 103-116, 1988.

Holliday, D. W. and Cutbill, J. L.: The Ebbadalen Formation (Carboniferous), Spitsbergen, P. Yorks. Geol. Soc., 39, 1-32, 1972.

Horsfield, W. T.: Glaucophane schists of Caledonian age from Spitsbergen, Geol. Mag., 109, 29-36, 1972.

Izquierdo-Llavall, E., Roca, E., Xie, H., Pla, O., Muñoz, J.A., Rowan, M. G., Yuan, N., and Huang, S.: Structural style of a fold-and-thrust belt involving laterally-changing, multiple décollements: the Kuqa fold-and-thrust belt (NW China), in: Fold and Thrust Belts: structural style, evolution and exploration, Petroleum Group of the Geological Society of London, 
31 October-2 November 2017, Burlington House, London, UK, 2017.

Jakobsson, M., Mayer, L., Coackley, B., Dowdeswell, J. A., Forbes, S., Fridman, B., Hodnesdal, H., Noormets, R., Pedersen, R., Rebesco, M., Schenke, H. W., Zarayskaya, Y., Accettella, D., Armstrong, A., Anderson, R. M., Bienhoff, P., Camerlenghi, A., Church, I., Edwards, M., Gardner, J. V., Hall, J. K., Hell, B., Hestvik, O., Kristoffersen, Y., Marcussen, C., Mohammad, R., Mosher, D., Nghiem, S. V., Pedrosa, M. T., Travaglini, P. G., and Weatherall, P.: The International Bathymetric Chart of the Arctic Ocean (IBCAO) Version 3.0, Geophys. Res. Lett., 39, L12609, https://doi.org/10.1029/2012GL052219, 2012.

Johannessen, E.: Facies analysis of the Ebbadalen Formation, Middle Carboniferous, Billefjorden Trough, Spitsbergen, unpublished Master's Thesis, University of Bergen, Bergen, Norway, 314 pp., 1980.

Johannessen, E. P. and Steel, R. J.: Mid-Carboniferous extension and rift-infill sequences in the Billefjorden Trough, Svalbard, Norsk Geol. Tidsskr., 72, 35-48, 1992.

Johansson, ̊. and Gee, D. G.: The late Palaeoproterozoic Eskolabreen granitoids of southern Ny Friesland, Svalbard Caledonides - geochemistry, age, and origin, GFF, 121, 113-126, 1999.

Johansson, Å., Larionov, A. N., Gee, D. G., Ohta, Y., Tebenkov, A. M., and Sandelin, S.: Greenvillian and Caledonian tectonomagmatic activity in northeasternmost Svalbard, in: The Neoproterozoic Timanide Orogen of Eastern Baltica, edited by: Gee, D. G. and Pease, V., Geol. Soc. London Memoirs, 30, 207-232, 2004.

Johansson, Å., Gee, D. G., Larionov, A. N., Ohta, Y., and Tebenkov, A. M.: Greenvillian and Caledonian evolution of eastern Svalbard - a tale of two orogenies, Terra Nova, 17, 317-325, 2005.

Koehl, J.-B.: Impact of Timanian thrusts on the Phanerozoic tectonic history of Svalbard, EGU General Assembly 2020, Online, 4-8 May 2020, EGU2020-2170, https://doi.org/10.5194/egusphere-egu2020-2170, 2020.

Koehl, J.-B. P.: Latest Devonian-Mississippian tectonic history of Bjørnøya, Solid Earth, in preparation, 2021a.

Koehl, J.-B. P.: Replication data for: "Early Cenozoic Eurekan strain partitioning and decoupling in central Spitsbergen, Svalbard", DataverseNO [data set], https://doi.org/10.18710/IIHGSH, 2021b.

Koehl, J.-B. P. and Muñoz-Barrera, J. M.: From widespread Mississippian to localized Pennsylvanian extension in central Spitsbergen, Svalbard, Solid Earth, 9, 1535-1558, https://doi.org/10.5194/se-9-1535-2018, 2018.

Koehl, J.-B. P., Tveranger, J., Osmundsen, P. T., Braathen, A., Taule, C., and Collombin, M.: Fault-growth deposit in a Carboniferous rift-basin: the Billefjorden Trough, Svalbard, Geophys. Res. Abstr., EGU2016-7131, EGU General Assembly 2016, Vienna, Austria, 2016.

Koehl, J.-B. P., Bergh, S. G., Henningsen, T., and Faleide, J. I.: Middle to Late Devonian-Carboniferous collapse basins on the Finnmark Platform and in the southwesternmost Nordkapp basin, SW Barents Sea, Solid Earth, 9, 341-372, https://doi.org/10.5194/se9-341-2018, 2018.

Koehl, J.-B. P., Collombin, M., Taule, C., Christophersen, G., Allaart, L., and Noormets, R.: Devonian-Carboniferous collapse and segmentation of the Billefjorden Trough, and Eurekan inversion-overprint and strain partitioning and decoupling along inherited WNW-ESE-striking faults, Norw. J. Geol., submitted, 2020.

Kośmińska, K., Majka, J., Mazur, S., Krumbholz, M., Klonowska, I., Manecki, M., Czerny, J., and Dwornik, M.: Blueschist facies metamorphism in Nordenskiöld Land of west-central Svalbard, Terra Nova, 26, 377-386, 2014.

Lamar, D. L. and Douglass, D. N.: Geology of an area astride the Billefjorden Fault Zone, Northern Dicksonland, Spitsbergen, Svalbard, Polarist. Skr., 197, 46 pp., 1995.

Lamar, D. L., Reed, W. E., and Douglass, D. N.: Structures bearing on the sense and magnitude of displacement and tectonic significance of Billefjorden Fault Zone, Dicksonland, Spitsbergen, Svalbard: Progress report, 1982 field season, Lamar-Merifield, Geologists, Technical report 82-6, 48 pp., 1982.

Lamar, D. L., Reed, W. E., and Douglass, D. N.: Billefjorden fault zone, Spitsbergen: Is it part of a major Late Devonian transform?, Geol. Soc. Am., 97, 1083-1088, 1986.

Larsen, B. T.: Tertiary thrust tectonics in the east of Spitsbergen, and implications for the plate-tectonic development of the NorthAtlantic, in: Tertiary Tectonics of Svalbard, edited by: Dallmann, W. K., Ohta, Y., and Andresen, A., Norsk Polarinstitutt Rapportserie, 46, 85-88, 1988.

Larssen, G. B., Elvebakk, G., Henriksen, S. E., Nilsson, I., Samuelsberg, T. J., Svånå, T. A., Stemmerik, L., and Worsley, D.: Upper Palaeozoic lithostratigraphy of the Southern Norwegian Barents Sea, Norwegian Petroleum Directorate Bulletin, 9, 1-76, 2002.

Lindemann, F.-J., Volohonsky, E., and Marshall, J. E.: A bonebed in the Hørbybreen Formation (Fammenian-Viséan) on Spitsbergen, NGF Abstracts and Proceedings, 1, Winter Meeting, 8-10 January 2013, Oslo, 2013.

Livshitz, J. J.: New data on the geological structure of the Pyramiden area (Vestspitsbergen), Uchenie Zapiski (Inst. Geol. Arctic) Regional'naya geologiya (NIIGA), 9, 36-56, 1966.

Lowell, J. D.: Spitsbergen Tertiary Orogenic Belt and the Spitsbergen Fracture Zone, Geol. Soc. Am. Bull., 83, 3091-3102, 1972.

Lønøy, A.: A Mid-Carboniferous, carbonate-dominated platform, Central Spitsbergen, Norsk Geol. Tidsskr., 75, 48-63, 1995.

Maher, H. D.: Structure and stratigraphy of the Midterhuken peninsula, Bellsund, west Spitsbergen, $\mathrm{PhD}$ Thesis, University of Wisconsin-Madison, Madison, USA, 437 pp., 1984.

Maher Jr., H. D.: Photointerpretation of Tertiary structures in platform cover strata of interior Oscar II Land, Spitsbergen, Polar Res., 6, 155-172, 1988.

Maher Jr., H. D.: Atypical rifting during the Carboniferous of the NW Barents Shelf, Report for Saga Petroleum, November 1996, 1996.

Maher Jr., H. D. and Braathen, A.: Løvehovden fault and Billefjorden rift basin segmentation and development, Spitsbergen, Norway, Geol. Mag., 148, 154-170, 2011.

Maher Jr., H. D. and Welbon, A. I.: Influence of Carboniferous structures on Tertiary tectonism at St. Jonsfjorden and Bellsund, Western Svalbard, Norsk Geol. Tidsskr., 72, 67-75, 1992.

Maher Jr., H. D., Craddock, C., and Maher, K.: Kinematics of Tertiary structures in upper Paleozoic and Mesozoic strata on Midterhuken, west Spitsbergen, Geol. Soc. Am. Bull., 97, 14111421, 1986. 
Manby, G. M. and Lyberis, N.: Tectonic evolution of the Devonian Basin of northern Spitsbergen, Norsk Geol. Tidsskr., 72, 7-19, 1992.

Manby, G. M. and Michalski, K.: Contrasting metamorphic terranes of Ny-Friesland and their place in the Arctic Caledonides, in: SvalGeoBase: Proterozoic and Lower Palaeozoic basement of Svalbard - state of knowledge and new perspectives of investigations, Workshop report, January 2014, edited by: Dallmann, W. K., Manecki, M., Michalski, K., and Glowacki, P., Tromsø, 2014.

Manby, G. M., Lyberis, N., Chorowicz, J., and Thiedig, F.: PostCaledonian tectonics along the Billefjorden fault zone, Svalbard, and implications for the Arctic region, Geol. Soc. Am. Bull., 105, 201-216, 1994.

Marshall, J., Lindemann, F. J., Finney, S., and Berry, C.: A Mid Fammenian (Late Devonian) spore assemblage from Svalbard and its significance, CIMP Meeting, 17-18 September 2015, Bergen, Norway, 2015.

McCann, A. J.: The Billefjorden Fault Zone, Dickson Land, Svalbard: Basement fault control on cover deformation, $\mathrm{PhD}$ Thesis, Imperial College, London, UK, 1993.

McCann, A. J.: Deformation of the Old Red Sandstone of NW Spitsbergen; links to the Ellesmerian and Caledonian orogenies, in: New Perspectives on the Old Red Sandstone, edited by: Friends, P. F. and Williams, B. P. J., Geol. Soc. Lond., 180, 567584, 2000.

McCann, A. J. and Dallmann, W. K.: Reactivation of the long-lived Billefjorden Fault Zone in north central Spitsbergen, Svalbard, Geol. Mag., 133, 63-84, 1996.

McClay, K. R.: Analogue models of inversion tectonics, Geol. Soc. Lond. Spec. Publ., 44, 41-59, 1989.

McClay, K. R.: Glossary of thrust tectonics terms, in: Thrust tectonics, edited by: McClay, K. R., London, Chapman and Hall, 419-433, 1992.

McClay, K. R. and Insley, M. W.: Duplex structures in the Lewis thrust sheet, Crowsnest Pass, Rocky Mountains, Alberta, Canada, J. Struct. Geol., 8, 911-922, 1986.

McWhae, J. R. H.: The major fault zone of central Vestspitsbergen, Q. J. Geol. Soc. Lond., 108, 209-232, 1953.

Michaelsen, B.: Strukturgeologie des svalbardischen Überschiebungs- und Faltengürtels im zentralen, östlichen Dickson Land, Spizbergen (Structural geology of the Svalbardian fold-and-thrust belt in central-eastern Dickson Land, Spitsbergen), Master's Thesis, University of Münster, Münster, Germany, 134 pp., 1998.

Michaelsen, B., Piepjohn, K., and Brinkmann, L.: Struktur und Entwicklung der svalbardischen Mimerelva Synkline im zentralen Dickson Land, Spitzbergen, Münster. Forsch. Geol. Paläont., 82, 203-214, 1997.

Molinda, G. M.: Geologic Hazards and Roof Stability in Coal Mines, Information Circular, 9466, U.S. Department of Health and Human Services, 2003.

Morley, C. K., von Hagke, C., Hansberry, R. L., Collins, A. S., Kanitpanyacharoen, W., and King, R.: Review of major shaledominated detachment and thrust characteristics in the diagenetic zone: Part I, meso- and macro-scopic scale, Earth-Sci. Rev., 173, 168-228, 2017.
Murascov, L. G. and Mokin, J. I.: Stratigraphic subdivision of the Devonian deposits of Spitsbergen, Polarinst. Skr., 167, 249-261, 1979.

Myhre, P. I., Corfu, F., and Andresen, A.: Caledonian anatexis of Greenvillian crust: a U/Pb study of Albert I Land, NW Svalbard, Norw. J. Geol., 89, 173-191, 2008.

Oakey, G. N. and Chalmers, J. A.: A new model for the Paleogene motion of Greenland relative to North America: Plate reconstructions of the Davis Strait and Nares Strait regions between Canada and Greenland, J. Geophys. Res., 117, B10401, https://doi.org/10.1029/2011JB008942, 2012.

Ohta, Y., Dallmeyer, R. D., and Peucat, J. J.: Caledonian terranes in Svalbard, GSA Spec. Paper, 230, 1-15, 1989.

Ohta, Y., Krasil'ščikov, A. A., Lepvrier, C., and Teben'kov, A. M.: Northern continuation of Caledonian high-pressure metamorphic rocks in central-western Spitsbergen, Polar Res., 14, 303-315, 1995.

Ohta, Y., Larionov, A. N., Tebenkov, A. M., Lepvrier, C., Maluski, H., Lange, M., and Hellebrandt, B.: Single-zircon Pb-evaporation and ${ }^{40} \mathrm{Ar} /{ }^{39} \mathrm{Ar}$ dating of the metamorphic and granitic rocks in north-west Spitsbergen, Polar Res., 21, 73-89, 2002.

Pčelina, T. M., Bogač, S. I., and Gavrilov, B. P.: Novye dannye po litostratigrafii devonskih otloženji rajona Mimerdalen arhipelaga Špicbergen [New data on the lithostratigraphy of the Devonian deposits of the region of Mimerdalen of the Svalbard Archipelago], in: Geologija osadocnogo cehla arhipelaga Špicbergen (Geology of the sedimentary blanket of the archipelago of Spitsbergen), edited by: Krasil'̌šikov, A. A. and Mirzaev, M. N., Leningrad: Sevmorgeologija, 7-19, 1986.

Petersen, T. G., Thomsen, T. B., Olaussen, S., and Stemmerik, L.: Provenance shifts in an evolving Eurekan foreland basin: the Tertiary Central Basin, Spitsbergen, J. Geol. Soc., 173, 634-648, 2016.

Phillipson, S. E.: The control of coal bed decollement-related slickensides on roof falls in North American Late Paleozoic coal basins, Int. J. Coal Geol., 53, 181-195, 2003.

Phillipson, S. E.: Effects of late Paleozoic foreland deformation on underground coal mine ground instability, Illinois and Appalachians Basins, Int. J. Coal Geol., 64, 3-19, 2005.

Piepjohn, K.: The Svalbardian-Ellesmerian deformation of the Old Red Sandstone and the pre-Devonian basement in NW Spitsbergen (Svalbard), in: New Perspectives on the Old Red Sandstone, edited by: Friend, P. F. and Williams, B. P. J., Geol. Soc. Lond. Spec. Publ., 180, 585-601, 2000.

Piepjohn, K. and Dallmann, W. K.: Stratigraphy of the uppermost Old Red Sandstone of Svalbard (Mimerdalen Subgroup), Polar Res., 33, 19998, https://doi.org/10.3402/polar.v33.19998, 2014.

Piepjohn, K., Brinkmann, L., Dißmann, B., Grewing, A., Michaelsen, B., and Kerp, H.: Geologische und strukturelle Entwicklung des Devon sim zentralen Dickson Land, Spitzbergen, Münster. Forsch. Geol. Paläont., 82, 175-202, 1997.

Piepjohn, K., Brinkmann, L., Grewing, A., and Kerp, H.: New data on the age of the uppermost ORS and the lowermost post-ORS strata in Dickson Land (Spitsbergen) and implications for the age of the Svalbardian deformation, in: New Perspectives on the Old Red Sandstone, edited by: Friend, P. F. and Williams, B. P. J., Geol. Soc. Lond. Spec. Publ., 180, 603-609, 2000.

Piepjohn, K., Thiedig, F., and Manby, G. M.: Nappe Stacking on Brøggerhalvøya, NW Spitsbergen, Geol. Jb. B, 91, 55-79, 2001. 
Prosser, S.: Rift-related linked depositional systems and their seismic expression, in: Tectonics and Seismic Sequence Stratigraphy, edited by: Williams, G. D. and Dobb, A., Geol. Soc. Lond. Spec. Publ., 71, 35-66, 1993.

Ringset, N. and Andresen, A.: The Gipshuken Fault System - Evidence for Tertiary thrusting along the Billefjorden Fault Zone, in: Tertiary Tectonics of Svalbard, edited by: Dallmann, W. K., Ohta, Y., and Andresen, A., Norsk Polarinstitutt Rapportserie, 46, 67-70, 1988.

Roy, J.-C. L. G.: La géologie du fossé des Vieux Grès Rouges du Spitzberg (archipel du Svalbard, territoire de l'Arctique) - Synthèse stratigraphique, consequences paléoenvironnementales et tectoniques synsédimentaires, Mémoires des sciences de la Terre de l'Université Pierre et Marie Curie, PhD Thesis, Pierre and Marie Curie University, Paris, France, 2007-15, 242 pp., 2007.

Roy, J.-C. L. G.: La saga des vieux grès rouges du Spitzberg (archipel du Svalbard, Arctique): Une histoire géologique et naturelle, Charenton-le-pont: Auto-Edition Roy-Poulain, 290 pp., 2009.

Saalman, K. and Thiedig, F.: Structural Evolution of the Tertiary West Spitsbergen Fold-and-Thrust Belt on Brøggerhalvøya, NWSpitsbergen, Polarforschung, 68, 111-119, 2000.

Saalman, K. and Thiedig, F.: Tertiary West Spitsbergen fold and thrust belt on Brøggerhalvøya, Svalbard: Structural evolution and kinematics, Tectonics, 20, 976-988, 2001.

Scheibner, C., Hartkopf-Fröder, C., Blomeier, D., and Forke, H.: The Mississippian (Lower Carboniferous) in northeast Spitsbergen (Svalbard) and a re-evaluation of the Billefjorden Group, Z. Dt. Ges. Geowiss., 163/3, 293-308, 2012.

Schlische, R. W.: Geometry and Origin of Fault-Related Folds in Extensional Settings, AAPG Bull., 79, 1661-1678, 1995.

Schweitzer, H.-J.: Die Devonfloren Spitzbergens [The Devonian flora of Spitsbergen], Palaeontographica Abteilung B Band, 252, Schweizerbart Science Publishers, Stuttgart, 1999.
Smyrak-Sikora, A. A., Johannessen, E. P., Olaussen, S., Sandal, G., and Braathen, A.: Sedimentary architecture during Carboniferous rift initiation - the arid Billefjorden Trough, Svalbard, J. Geol. Soc. Lond., 176, 225-252, 2018.

Stipp, M., Stünitz, H., Heilbronner, R., and Schmid, S. M.: The eastern Tonale fault zone: a "natural laboratory" for crystal plastic deformation of quartz over a temperature range from 250 to $700^{\circ}$ C, J. Struct. Geol., 24, 1861-1884, 2002.

Tonstad, S. A.: The Late Paleozoic development of the Ottar basin from seismic 3D interpretation, Master's Thesis, University of Troms $\varnothing$, Troms $\varnothing$, Norway, 135 pp., 2018.

Vigran, J. O.: Spores from Devonian deposits, Mimerdalen, Spitsbergen, Norsk Polarinstitutt Skrifter, 132, 49 pp., 1964.

Vogt, T.: The stratigraphy and tectonics of the Old Red formations of Spitsbergen, Abstracts of the Proceedings of the Geological Society London, 1343, 88, 1938.

Wang, G., Liu, Y., Gu, Y., Xiong, X., Yuan, K., Li, L., Zhou, H., Liu, J., and Shang, G.: Multi-Décollement Structure Modelling of Kuqa Fold-Thrust Belt in Tarim Basin, in: International Petroleum Technology Conference, 26-28 March 2013, Beijing, China, 2013.

Wilson, R. L. and Wojtal, S. F.: Cumberland Plateau décollement zone at Dunlap, Tennessee, GSA Centennail Field Guide - Southeastern Section, 143-148, 1986.

Witt-Nilsson, P., Gee, D. G., and Hellman, F. J.: Tectonostratigraphy of the Caledonian Atomfjella Antiform of northern Ny Friesland, Svalbard, Norsk Geol. Tidsskr., 78, 67-80, 1998.

Würtzen, C. L., Stemmerik, L., Olaussen, S., and Ahokas, J.: Facies analysis of the uppermost Devonian to Lower Carboniferous Billefjorden Group, central Spitsbergen, Svalbard, NGF Winter conference, 7-9 January 2019, Bergen, Norway, 2019. 